\title{
Directed lithiation of simple aromatics and heterocycles for synthesis of substituted derivatives
}

\author{
Gamal A. El-Hiti, ${ }^{a}{ }^{a}$ Keith Smith, ${ }^{* b}$ Amany S. Hegazy, ${ }^{b}$ \\ Mohammed B. Alshammari, ${ }^{c}$ and Ali M. Masmali ${ }^{a}$ \\ ${ }^{a}$ Cornea Research Chair, Department of Optometry, College of Applied Medical Sciences, \\ King Saud University, P.O. Box 10219, Riyadh 11433, Saudi Arabia \\ ${ }^{b}$ School of Chemistry, Cardiff University, Main Building, Park Place, \\ Cardiff, CF10 3AT, UK \\ ${ }^{c}$ Chemistry Department, College of Sciences and Humanities, \\ Salman bin Abdulaziz University, P.O. Box 83, Al-Kharij 11942, Saudi Arabia \\ E-mail:gelhiti@ksu.edu.sa,smithk13@cardiff.ac.uk
}

\section{Dedicated to Professor Manfred Schlosser to mark the scientific achievements within his career}

DOI: $\underline{\text { http://dx.doi.org/10.3998/ark.5550190.p008.744 }}$

\begin{abstract}
Directed lithiation of substituted aromatics and heterocycles containing a directing metalating group with alkyllithium in anhydrous tetrahydrofuran or diethyl ether at low temperature provides the corresponding lithium intermediates. Reaction of the lithium reagents obtained in situ with various electrophiles gives the corresponding substituted derivatives in high yields. The process has been applied for various derivatives and has proven to be a convenient method for modification of ring systems. This brief review highlights the importance of directing metalating groups in directed lithiation of simple aromatic compounds and some common heterocycles as a tool for regioselective substitution.
\end{abstract}

Keywords: Lithium reagents, directed lithiation, lithium intermediates, electrophiles, substituted aromatics, heterocycles, synthesis

\section{Table of Contents}

1. Introduction

2. Directed lithiation of benzenoid compounds

3. Directed lithiation of naphthalenes 
4. Directed lithiation of heterocycles

4.1. Directed lithiation of pyridines

4.1.1 Directed lithiation of 2-substituted pyridines

4.1.2 Directed lithiation of 3-substituted pyridines

4.1.3 Directed lithiation of 4-substituted pyridines

4.2 Directed ortho-lithiation of quinolines

4.3 Directed ortho-lithiation of diazines

4.3.1 Directed ortho-lithiation of 1,2-diazines

4.3.2 Directed ortho-lithiation of 1,3-diazines

4.3.3 Directed ortho-lithiation of 1,4-diazines

4.4 Directed ortho-lithiation of cinnolines

4.5 Directed ortho-lithiation of $3 H$-quinazolin-4-ones

4.6 Directed ortho-lithiation of quinoxalines

4.7 Directed ortho-lithiation of other heterocycles

5. Conclusions

6. Acknowledgements

References

\section{Introduction}

Electrophilic aromatic substitution reactions are commonly used for the synthesis of various types of valuable chemicals. However, industry still often relies on technologies developed many years ago for the production of such chemicals. Consequently, many current industrial processes suffer serious disadvantages, including the use of large quantities of mineral or Lewis acids as activators, which could generate large quantities of toxic and corrosive waste by-products during the work-up. They also frequently involve use of stoichiometric quantities of toxic reagents and/or produce mixtures of regioisomers that require separation. ${ }^{1-3}$

Recently, many efforts have been made to develop cleaner and environmentally friendlier processes for the production of single isomeric products. Solids such as zeolites can play an important role in the development of greener organic syntheses for the production of paraisomers through their abilities to act as heterogeneous catalysts. ${ }^{4-12}$ While zeolites offer routes to para-substituted products via shape selectivity, organolithiums play an important role for the clean production of ortho-products. Various substituted aromatics and heterocycles undergo lithiation ortho to a directing metalating group to produce useful intermediates for the synthesis of ortho-disubstituted derivatives. ${ }^{13-41}$

Synthesis of isomerically pure ortho-disubstituted aromatics is a significant goal in synthetic chemistry, but simple aromatic electrophilic substitution reactions often produce mixtures of isomers. ${ }^{42}$ ortho-Lithiation followed by reaction with an electrophile is one of the most efficient 
alternatives. Directed transition metal catalyzed $\mathrm{C}-\mathrm{H}$ bond activation and functionalization is an alternative approach to ortho-substituted systems. ${ }^{43-47}$

The reactions of substituted aromatics with lithium reagents usually take place at low temperatures, in practice at $-78{ }^{\circ} \mathrm{C}$ in the presence of anhydrous solvent. Diethyl ether $\left(\mathrm{Et}_{2} \mathrm{O}\right)$ is easily dried, has an appropriate boiling point and a low enough freezing point and therefore it is one of the most commonly used solvents for lithiation reactions. ${ }^{18}$ Moreover, most lithium reagents are soluble in diethyl ether and do not cleave the ether too rapidly. Also, tetrahydrofuran (THF) is widely used as an alternative to diethyl ether when a more strongly Lewis-basic solvent is required. ${ }^{18}$

Directed ortho-lithiation of an aromatic compound $\mathbf{1}$ involves removal of a proton from a site ortho to a directing metalating group (DMG) that incorporates a heteroatom, usually oxygen, nitrogen or sulfur. The base, normally an alkyllithium, leads to the production of ortho-lithiated species 3 via initial coordination of the lithium species to the DMG (2, Scheme 1). Reaction of $\mathbf{3}$ with electrophiles produces the corresponding ortho-disubstituted products $4 .{ }^{18-41}$ It appears that the complexation between the DMG and the lithium reagent prior to lithiation serves to bring the lithium reagent into closer proximity with the ortho proton, which is then selectively removed. $^{48,49}$

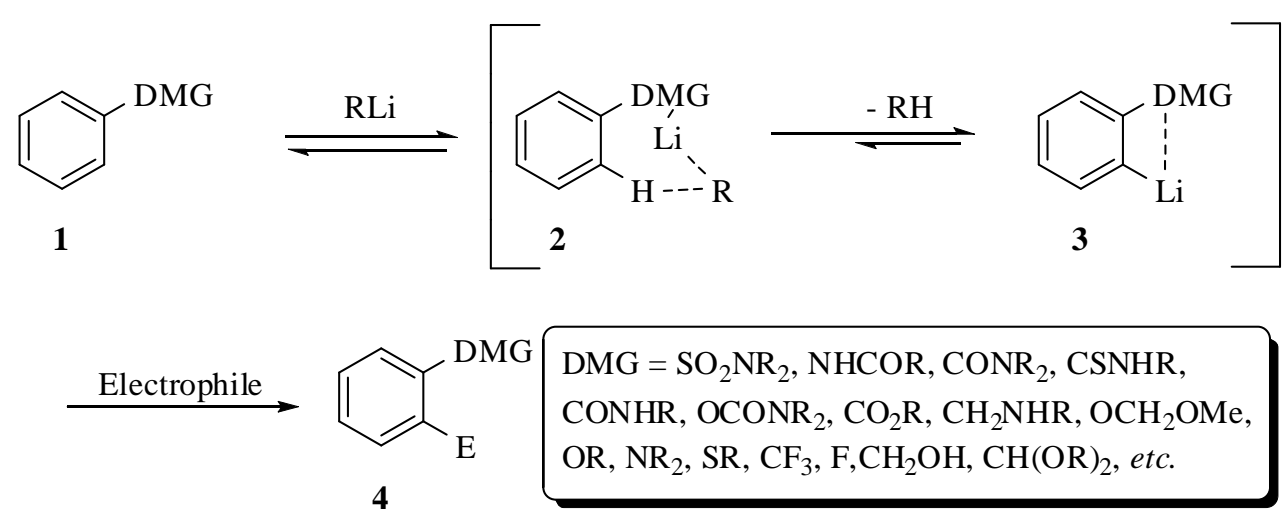

Scheme 1. Directed lithiation of substituted aromatics 1 followed by reactions with electrophiles.

Successful deprotonation requires the DMG to be a good coordinating site for the lithium reagent and at the same time a poor electrophilic site for attack by the lithium reagent. Strong directing metalating groups that encourage ortho-lithiation include $\mathrm{SO}_{2} \mathrm{NR}_{2}, \mathrm{NHCOR}, \mathrm{CONR}_{2}$, CSNHR, CONHR, OCONR $2, \mathrm{CO}_{2} \mathrm{R}, \mathrm{CH}_{2} \mathrm{NHR}, \mathrm{OCH}_{2} \mathrm{OMe}$. Moderate DMGs include OR, $\mathrm{NR}_{2}$, $\mathrm{SR}, \mathrm{CF}_{3}$ and $\mathrm{F}$, while weak DMGs include $\mathrm{CH}_{2} \mathrm{OH}$ and $\mathrm{CH}(\mathrm{OR})_{2} .{ }^{50}$ Along with others, we have shown that use of organolithium intermediates is an important strategy for the synthesis of regiospecifically substituted aromatics and heterocycles. ${ }^{51-80}$ 


\section{Directed lithiation of benzenoid compounds}

Directed lithiation of substituted benzenes 1, having various DMGs, with a lithium reagent produces lithium intermediates $\mathbf{3}$, which react with electrophiles to produce the corresponding substituted benzenes 4 (Scheme 2). ${ }^{23,24}$ For example, double lithiation of $N$-pivaloylaniline, on nitrogen and on the carbon at position 2 , by use of two molar equivalents of $n$-butyllithium $\left(n\right.$-BuLi) at $0{ }^{\circ} \mathrm{C}$ in anhydrous THF (Scheme 2, 1; DMG $=\mathrm{NHCOBu}^{t}$ ) produces a dilithium intermediate in-situ, which reacts with electrophiles to give the corresponding ortho-substituted derivatives $\left(\mathrm{DMG}=\mathrm{NHCO}^{t} \mathrm{Bu}\right)$ in high yields. ${ }^{81}$ Some examples of substituted benzenes $\mathbf{1}$ that have been subjected to directed lithiation reactions, along with the relevant reaction conditions, are shown in Table 1.

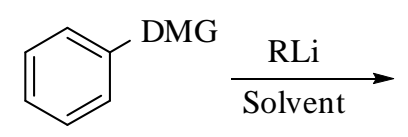

1

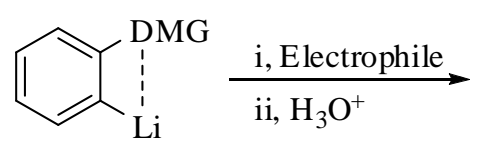

3<smiles>Cc1ccccc1F</smiles>

4

$\mathrm{DMG}=\mathrm{NHCO}^{t} \mathrm{Bu}, \mathrm{NHCO}_{2}{ }^{t} \mathrm{Bu}, \mathrm{NHCONMe}_{2}, \mathrm{CH}_{2} \mathrm{NHCO}^{t} \mathrm{Bu}, \mathrm{CH}_{2} \mathrm{NHCONMe}_{2}$

$\mathrm{CH}_{2} \mathrm{CH}_{2} \mathrm{NHCO}^{t} \mathrm{Bu}, \mathrm{CH}_{2} \mathrm{CH}_{2} \mathrm{NHCONMe}_{2}, \mathrm{CH}_{2} \mathrm{CH}_{2} \mathrm{NHCO}_{2}{ }^{t} \mathrm{Bu}, \mathrm{CONHMe}$,

CONHPh, CONEt $2, \mathrm{CON}^{i} \mathrm{Pr}_{2}, \mathrm{CON}(\mathrm{Me})^{t} \mathrm{Bu}, \mathrm{OCONEt}_{2}, \mathrm{CH}_{2} \mathrm{NEt}_{2}$, OTHP,

DHDPO, $1 H$-tetrazol-5-yl, OMe, SH, $\mathrm{CF}_{3}, \mathrm{~F}$

Scheme 2. Directed lithiation of substituted benzenes $\mathbf{1}$.

Table 1. Examples of substituted benzenes 1 lithiated according to Scheme 2

\begin{tabular}{|c|c|c|c|c|}
\hline \multirow[t]{2}{*}{ DMG } & \multicolumn{3}{|c|}{ Reaction conditions } & \multirow[t]{2}{*}{ Reference } \\
\hline & $\mathrm{RLi}$ & Solvent & $\mathrm{T}\left({ }^{\circ} \mathrm{C}\right)$ & \\
\hline $\mathrm{NHCO}^{t} \mathrm{Bu}$ & $n$-BuLi & THF & 0 & 81 \\
\hline $\mathrm{NHCO}_{2}{ }^{t} \mathrm{Bu}$ & $t$-BuLi & THF & -20 & 82,83 \\
\hline $\mathrm{NHCONMe}_{2}$ & $n$-BuLi & THF & -78 & 84 \\
\hline $\mathrm{CH}_{2} \mathrm{NHCO}^{t} \mathrm{Bu}$ & $t$-BuLi & THF & -78 & 73 \\
\hline $\mathrm{CH}_{2} \mathrm{NHCO}^{t} \mathrm{Bu}$ & $n$-BuLi & THF & 0 & 85 \\
\hline $\mathrm{CH}_{2} \mathrm{NHCONMe}_{2}$ & $t$-BuLi & THF & -78 & 73 \\
\hline $\mathrm{CH}_{2} \mathrm{NHCONMe}_{2}$ & sec-BuLi & THF & -50 & 86 \\
\hline $\mathrm{CH}_{2} \mathrm{CH}_{2} \mathrm{NHCO}^{t} \mathrm{Bu}$ & n-BuLi & THF & -20 to 0 & 87 \\
\hline $\mathrm{CH}_{2} \mathrm{CH}_{2} \mathrm{NHCONMe}_{2}$ & $n$-BuLi & THF & -20 to 0 & 88 \\
\hline $\mathrm{CH}_{2} \mathrm{CH}_{2} \mathrm{NHCO}_{2}{ }^{t} \mathrm{Bu}$ & $n$-BuLi & THF & -20 to 0 & 88 \\
\hline CONHMe & $n$-BuLi & THF & -78 & 89 \\
\hline $\mathrm{CONHPh}$ & $n$-BuLi & THF & -78 & 89 \\
\hline $\mathrm{CONEt}_{2}$ & $s e c-\mathrm{BuLi}$ & THF/TMEDA $^{a}$ & -78 & 90,91 \\
\hline
\end{tabular}




\begin{tabular}{|c|c|c|c|c|}
\hline Table 1 (continued) & & & & \\
\hline $\mathrm{CON}^{i} \operatorname{Pr}_{2}$ & sec-BuLi & THF & -78 & 92 \\
\hline $\mathrm{CON}^{i} \operatorname{Pr}_{2}$ & n-BuLi & THF & -78 & 93 \\
\hline $\mathrm{CON}(\mathrm{Me})^{t} \mathrm{Bu}$ & $s e c-\mathrm{BuLi}$ & THF/TMEDA $^{a}$ & -78 & 94 \\
\hline $\mathrm{OCONEt}_{2}$ & $s e c-\mathrm{BuLi}$ & THF/TMEDA $^{a}$ & -78 & 95 \\
\hline $\mathrm{CH}_{2} \mathrm{NEt}_{2}$ & $t-\mathrm{BuLi} / \mathrm{ZnCl}_{2}$ & $\mathrm{THF} / \mathrm{Et}_{2} \mathrm{O}(1: 1)$ & -78 to 0 & 96 \\
\hline $\mathrm{OTHP}^{b}$ & n-BuLi & THF/TMEDA $^{a}$ & -20 to -10 & 97 \\
\hline $\mathrm{DHDPO}^{c}$ & $i$-PrLi & $\mathrm{THF}^{\mathrm{DMMPU}}{ }^{d}$ & -98 to -40 & 75 \\
\hline $1 H$-tetrazol-5-yl & $s e c-\mathrm{BuLi}$ & THF & -78 & 98 \\
\hline $\mathrm{OMe}$ & $t$-BuLi & THF & -78 & 99 \\
\hline $\mathrm{OMe}$ & $n$-BuLi & THF & -75 & 100 \\
\hline $\mathrm{OMe}$ & $n$-BuLi & THF/TMEDA $^{a}$ & -108 to -78 & 101 \\
\hline $\mathrm{OMe}$ & $n$-BuLi & $\mathrm{THF} / \mathrm{KO}^{t} \mathrm{Bu}$ & -95 & 102 \\
\hline $\mathrm{SH}$ & $n$-BuLi & cyclohexane/TMEDA $^{a}$ & 0 to 25 & 103,104 \\
\hline $\mathrm{SH}$ & $n$-BuLi & TMEDA $^{a}$ & 20 & 105 \\
\hline $\mathrm{CF}_{3}$ & $\operatorname{LTMP}^{e}$ & THF & -75 & 106 \\
\hline $\mathrm{F}$ & $n$-BuLi & $\mathrm{Et}_{2} \mathrm{O}$ & -50 & 107 \\
\hline
\end{tabular}

${ }^{a}$ TMEDA is $N, N, N^{\prime}, N^{\prime}$-tetramethylethylenediamine. ${ }^{b}$ OTHP is $O$-tetrahydropyranyl. ${ }^{c}$ DHDPO is 4,5-dihydro-4,5-diphenyloxazol-2-yl. ${ }^{d}$ DMPU is $N, N^{\prime}$-dimethylpropyleneurea (1,3-dimethyltetrahydropyrimidin-2(1H)-one). ${ }^{e}$ LTMP is lithium 2,2,6,6-tetramethylpiperidide

\section{Directed lithiation of naphthalenes}

Directed lithiation of substituted naphthalenes having DMGs has received limited attention compared to benzene derivatives. ${ }^{108-115}$ However, there are some useful reports. For example, $N, N$-diethyl-1-naphthoamide (5) has been lithiated with sec-BuLi in the presence of $N, N, N^{\prime}, N^{\prime}$ tetramethylethylenediamine (TMEDA) at $-78{ }^{\circ} \mathrm{C}$ in THF. The lithium intermediate 6 thus obtained has been reacted with oxygen to give 2-hydroxy- $N, N$-diethyl-1-naphthoamide (7; Scheme 3). ${ }^{108,109}$ Similarly, lithiation and substitution of $N, N$-diethyl-2-naphthoamide produced the corresponding 1 -substituted $N, N$-diethyl-2-naphthamides. ${ }^{108}$

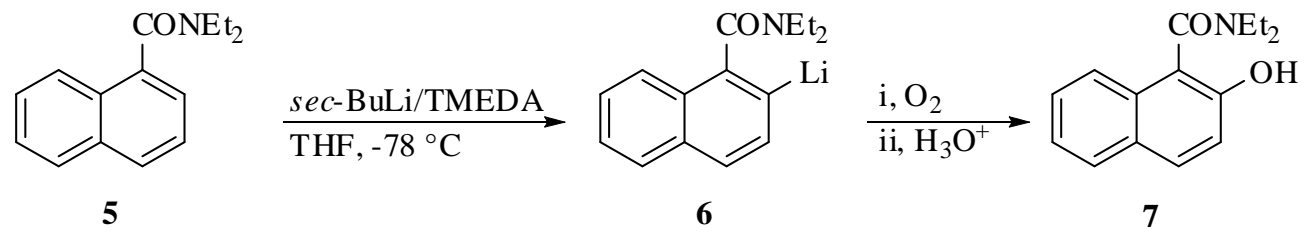

Scheme 3. Directed lithiation of $N, N$-diethyl-1-naphthoamide (5). 


\section{Directed lithiation of heterocycles}

Many valuable bioorganic and pharmaceutical compounds contain a heterocyclic base unit, the synthesis of which is therefore extremely important. Use of organolithium intermediates is an efficient process for ortho-functionalization of $\pi$-deficient heteroaromatics such as pyridine, quinoline, isoquinoline and diazines. ${ }^{58}$ In many cases, the lithiation reaction requires use of less nucleophilic lithium reagents such as lithium diisopropylamide (LDA) and lithium 2,2,6,6tetramethylpiperidide (LTMP) to avoid nucleophilic addition of alkyllithiums to the azomethine $(\mathrm{C}=\mathrm{N})$ bond, even at low temperature.

\subsection{Directed lithiation of pyridines}

4.1.1 Directed lithiation of 2-substituted pyridines. Directed lithiation of pyridines 8 containing a DMG at the C-2 position takes place at the 3-position to provide the corresponding lithium intermediates 9 (Scheme 4). ${ }^{116-138}$ Reactions of 9 with electrophiles provide the corresponding substituted derivatives 10 (Scheme 4). For example, successful C-3 lithiation of 2-(pivaloylamino)pyridine (Scheme $3 ; \mathrm{DMG}=\mathrm{NHCO}^{t} \mathrm{Bu}$ ) took place with $n$-BuLi in THF at 0 ${ }^{\circ} \mathrm{C} .{ }^{116,117}$ Some examples of 2 -substituted pyridines 8 that have been subjected to directed lithiation, along with the appropriate reaction conditions, are shown in Table 2.

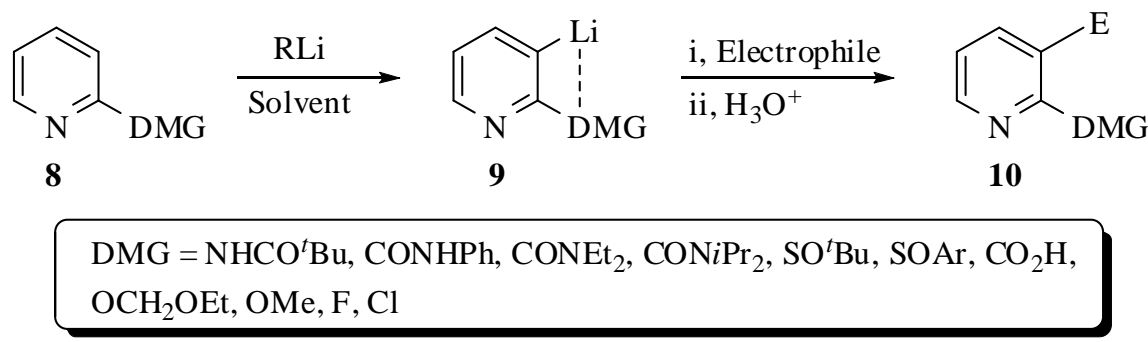

Scheme 4. Directed lithiation of substituted pyridines 8 .

Table 2. Examples of 2-substituted pyridines 8 lithiated according to Scheme 4

\begin{tabular}{ccccc}
\hline $\mathrm{DMG}$ & $\mathrm{RLi}$ & Solvent & $\mathrm{T}\left({ }^{\circ} \mathrm{C}\right)$ & Reference \\
\hline $\mathrm{NHCO}{ }^{t} \mathrm{Bu}$ & $n-\mathrm{BuLi}$ & $\mathrm{THF}$ & 0 & 116,117 \\
$\mathrm{CONHPh}$ & $n-\mathrm{BuLi}$ & $\mathrm{THF}$ & -78 & 118 \\
$\mathrm{CONHPh}$ & $\mathrm{LDA}$ & $\mathrm{THF}$ & -78 & 119 \\
$\mathrm{CONEt}_{2}$ & $s e c-\mathrm{BuLi}$ & $\mathrm{THF}$ & -78 & 120 \\
$\mathrm{CONEt}_{2}$ & $\mathrm{LDA}$ & $\mathrm{Et} \mathrm{t}_{2} \mathrm{O}$ & -78 & 121 \\
$\mathrm{CON}^{i} \mathrm{Pr}_{2}$ & $n-\mathrm{BuLi}$ & $\mathrm{THF}$ & -78 & 122 \\
$\mathrm{CON}^{i} \mathrm{Pr}_{2}$ & $\mathrm{LDA}$ & $\mathrm{Et}_{2} \mathrm{O}$ & -78 & 123 \\
\hline
\end{tabular}


Table 2 (continued)

\begin{tabular}{|c|c|c|c|c|}
\hline DMG & $\mathrm{RLi}$ & Solvent & $\mathrm{T}\left({ }^{\circ} \mathrm{C}\right)$ & Reference \\
\hline $\mathrm{CON}^{i} \operatorname{Pr}_{2}$ & sec-BuLi & THF/TMEDA & -78 & 124 \\
\hline $\mathrm{SO}^{t} \mathrm{Bu}$ & LDA & THF & -78 & 125 \\
\hline SOAr & LDA & THF & -78 & 126,127 \\
\hline $\mathrm{CO}_{2} \mathrm{H}$ & $n$-BuLi/LTMP & THF & -75 to 0 & 128,129 \\
\hline $\mathrm{OCH}_{2} \mathrm{OEt}$ & n-BuLi & THF & -10 & 130,131 \\
\hline $\mathrm{OMe}$ & $n-\mathrm{BuLi} / \mathrm{LDMAE}^{a}$ & hexane & 0 & 132 \\
\hline $\mathrm{F}$ & LDA & THF & -75 & 133 \\
\hline $\mathrm{F}$ & $\mathrm{PhLi} / \mathrm{DIA}^{b}$ & THF & -50 & 134 \\
\hline $\mathrm{F}$ & $n-\mathrm{BuLi} /{ }^{t} \mathrm{BuOK}$ & THF & -75 & 135 \\
\hline $\mathrm{Cl}$ & $n$-BuLi or LDA & THF & -80 & 136 \\
\hline $\mathrm{Cl}$ & LDA & THF & -85 & 137 \\
\hline $\mathrm{Cl}$ & $\mathrm{PhLi} / \mathrm{DIA}^{b}$ & THF & -40 & 134 \\
\hline $\mathrm{Cl}$ & LTMP & THF & -78 & 138 \\
\hline
\end{tabular}

${ }^{a}$ LDMAE is lithium 2-dimethylaminoethanolate. ${ }^{b}$ DIA is diisopropylamine.

4.1.2 Directed lithiation of 3-substituted pyridines. Directed lithiation of 3-substituted pyridines 11 with various lithium reagents takes place predominately at C-4 to give the corresponding lithium intermediates 12 (Scheme 5). Reactions of $\mathbf{1 2}$ with electrophiles produce the corresponding substituted pyridines 13. ${ }^{121,123,128,129,135,139-159}$ Some examples of 3-substituted pyridines $\mathbf{1 1}$ that have been subjected to directed lithiation, along with the appropriate reaction conditions, are recorded in Table 3.

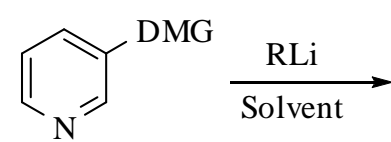

11

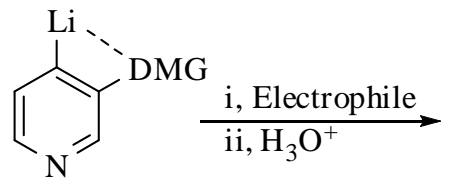

12<smiles>Cc1cnccc1F</smiles>

13

$\mathrm{DMG}=\mathrm{SO}_{2} \mathrm{NH}^{t} \mathrm{Bu}, \mathrm{NHCO}^{t} \mathrm{Bu}, \mathrm{NHCO}_{2}{ }^{t} \mathrm{Bu}, \mathrm{CH}_{2} \mathrm{NHCO}^{t} \mathrm{Bu}, \mathrm{CH}_{2} \mathrm{NHCO}_{2}{ }^{t} \mathrm{Bu}$, $\mathrm{CH}_{2} \mathrm{NHCONMe}_{2}, \mathrm{CONEt}_{2}, \mathrm{CONiPr}_{2}, \mathrm{OCSNEt}_{2}, \mathrm{SOAr}, \mathrm{CO}_{2} \mathrm{H}, \mathrm{OMe}$, OEt, F, $\mathrm{Br}, \mathrm{Cl}$

Scheme 5. Directed lithiation of 3-substituted pyridines 11. 
Table 3. Examples of 3-substituted pyridines 11 lithiated according to Scheme 5

\begin{tabular}{|c|c|c|c|c|}
\hline DMG & RLi & Solvent & $\mathrm{T}\left({ }^{\circ} \mathrm{C}\right)$ & Reference \\
\hline $\mathrm{SO}_{2} \mathrm{NH}^{t} \mathrm{Bu}$ & $t$-BuLi & THF & -78 & 139 \\
\hline $\mathrm{NHCO}^{t} \mathrm{Bu}$ & $n-\mathrm{BuLi}$ & $\mathrm{THF} / \mathrm{Et}_{2} \mathrm{O} / \mathrm{TMEDA}$ & -70 to -30 & 140 \\
\hline $\mathrm{NHCO}^{t} \mathrm{Bu}$ & $n$-BuLi & THF/TMEDA & -25 & 141,142 \\
\hline $\mathrm{NHCO}_{2}{ }^{t} \mathrm{Bu}$ & $n$-BuLi & THF & -20 & 142 \\
\hline $\mathrm{NHCO}_{2}{ }^{t} \mathrm{Bu}$ & $n$-BuLi & $\mathrm{Et}_{2} \mathrm{O} / \mathrm{TMEDA}$ & -10 & 143 \\
\hline $\mathrm{CH}_{2} \mathrm{NHCO}^{t} \mathrm{Bu}$ & $t$-BuLi & THF & -78 & 144 \\
\hline $\mathrm{CH}_{2} \mathrm{NHCO}_{2}{ }^{t} \mathrm{Bu}$ & $t$-BuLi & THF & -78 & 144 \\
\hline $\mathrm{CH}_{2} \mathrm{NHCONMe}_{2}$ & $t$-BuLi & THF & -78 & 144 \\
\hline $\mathrm{CONEt}_{2}$ & LDA & $\mathrm{Et}_{2} \mathrm{O}$ & -78 & 121 \\
\hline $\mathrm{CONEt}_{2}$ & LDA & THF & -78 & 145 \\
\hline $\mathrm{CONEt}_{2}$ & $t$-BuLi & THF/TMEDA & -80 & 146 \\
\hline $\mathrm{CON}^{i} \mathrm{Pr}_{2}$ & LDA & $\mathrm{Et}_{2} \mathrm{O}$ & -78 & 123 \\
\hline $\mathrm{CON}^{i} \operatorname{Pr}_{2}$ & LTMP & THF/TMEDA & -80 & $146-148$ \\
\hline $\mathrm{OCSNEt}_{2}$ & LTMP & THF & -78 & 149 \\
\hline SOAr & LDA & THF & -75 & 150 \\
\hline $\mathrm{CO}_{2} \mathrm{H}$ & $n$-BuLi/LTMP & THF & -50 & 128 \\
\hline $\mathrm{CO}_{2} \mathrm{H}$ & $n$-BuLi/LTMP & THF & -75 & 129 \\
\hline $\mathrm{OMe}$ & n-BuLi & THF & 0 & 151 \\
\hline OEt & $\mathrm{MeLi}$ & $\mathrm{THF} / \mathrm{Et}_{2} \mathrm{O}$ & $\mathrm{RT}$ & 152 \\
\hline $\mathrm{F}$ & $n-\mathrm{BuLi} / t-\mathrm{BuOK}$ & THF & -75 & 135 \\
\hline $\mathrm{F}$ & $n$-BuLi & THF & -75 & 153 \\
\hline $\mathrm{F}$ & $n-\mathrm{BuLi}$ & THF & -78 & 154,155 \\
\hline $\mathrm{Br}$ & LDA & THF & -78 & 156,157 \\
\hline $\mathrm{Cl}$ & LDA & THF & -78 & 158,159 \\
\hline
\end{tabular}

4.1.3 Directed lithiation of 4-substituted pyridines. Directed lithiation of 4-substituted pyridines 14 takes place at C-3 to produce the corresponding 3-lithio intermediates $\mathbf{1 5}$ which on reactions with electrophiles give the corresponding 3,4-disubstituted pyridines (16; Scheme 6). ${ }^{16,118,121,123,128,129,159-163}$ Some examples of 4-substituted pyridines $\mathbf{1 4}$ that have been subjected to directed lithiation, along with the appropriate reaction conditions, are shown in Table 4. 


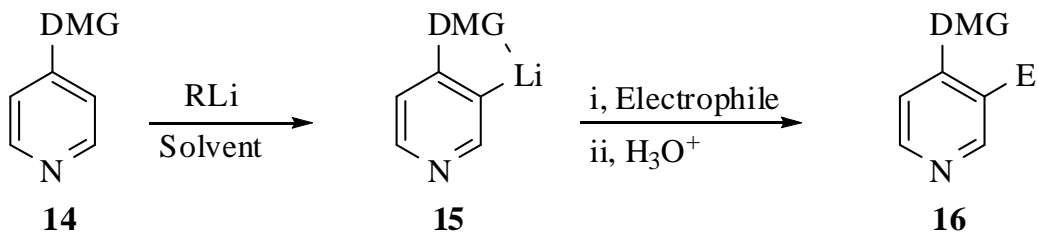

$\mathrm{DMG}=\mathrm{NHCO}^{t} \mathrm{Bu}, \mathrm{CONEt}_{2}, \mathrm{CON}^{i} \mathrm{Pr}_{2}, \mathrm{CONHPh}, \mathrm{CO}_{2} \mathrm{H}, \mathrm{CH}(\mathrm{OEt})_{2}$, $\mathrm{OMe}, \mathrm{Br}, \mathrm{Cl}$

Scheme 6. Directed lithiation of 4-subtituted pyridines 14.

Table 4. Examples of 4-substituted pyridines 14 lithiated according to Scheme 6

\begin{tabular}{|c|c|c|c|c|}
\hline DMG & $\mathrm{RLi}$ & Solvent & $\mathrm{T}\left({ }^{\circ} \mathrm{C}\right)$ & Reference \\
\hline $\mathrm{NHCO}^{t} \mathrm{Bu}$ & $n$-BuLi & THF & 0 & 116,160 \\
\hline $\mathrm{CONEt}_{2}$ & LDA & $\mathrm{Et}_{2} \mathrm{O}$ & -78 & 121 \\
\hline $\mathrm{CON}^{i} \mathrm{Pr}_{2}$ & LDA & $\mathrm{Et}_{2} \mathrm{O}$ & -78 & 123 \\
\hline CONHPh & $n$-BuLi & THF & -78 & 118 \\
\hline $\mathrm{CO}_{2} \mathrm{H}$ & $n$-BuLi/LTMP & THF & -50 to -25 & 128 \\
\hline $\mathrm{CO}_{2} \mathrm{H}$ & $n$-BuLi/LTMP & THF & -75 to -25 & 129 \\
\hline $\mathrm{CH}(\mathrm{OEt})_{2}$ & LDA & THF & -78 & 161 \\
\hline $\mathrm{OMe}$ & $\mathrm{PhLi}$ & THF & 0 & 162 \\
\hline $\mathrm{Br}$ & LDA & THF & -78 & 163 \\
\hline $\mathrm{Cl}$ & $n-\mathrm{BuLi}$ & $\mathrm{Et}_{2} \mathrm{O} / \mathrm{TMEDA}$ & -70 & 159 \\
\hline $\mathrm{Cl}$ & LDA & THF & -70 & 159 \\
\hline
\end{tabular}

\subsection{Directed ortho-lithiation of quinolines}

Directed lithiation of various substituted quinolines has been achieved by the use of less nucleophilic lithium reagents at low temperatures. ${ }^{164-173}$ For example, directed lithiation of 2-substituted quinolines 17 with LDA gives the corresponding lithium reagents 18 which on reactions with electrophiles produce the corresponding 2,3-disubstuited quinolines 19 (Scheme 7) in moderate to very good yields. ${ }^{166-169}$ Some examples of 2-substituted quinolines $\mathbf{1 7}$ that have been subjected to directed lithiation, along with the appropriate reaction conditions, are shown in Table 5. Similarly, directed lithiation of 3-fluoroquinolines was achieved at the C-4 position by the use of LDA in THF or a THF/hexane mixture at low temperatures. ${ }^{135,170,171}$<smiles>COc1ccc2ccccc2n1</smiles>

17<smiles>C[Te]c1nc2ccccc2cc1[AlH]</smiles>

18

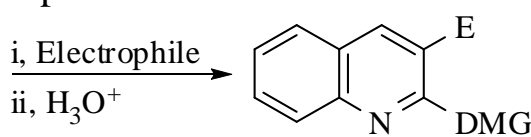

19

$\mathrm{DMG}=\mathrm{NHCO}^{t} \mathrm{Bu}, \mathrm{OCONEt}_{2}, \mathrm{CO}_{2} \mathrm{H}, \mathrm{OR}, \mathrm{Cl}$

Scheme 7. Directed lithiation of 2-substituted quinolines 17. 
Table 5. Examples of 2-substituted quinolines 17 lithiated according to Scheme 7

\begin{tabular}{ccccc}
\hline $\mathrm{DMG}$ & $\mathrm{RLi}$ & Solvent & $\mathrm{T}\left({ }^{\circ} \mathrm{C}\right)$ & Reference \\
\hline $\mathrm{NHCO}^{t} \mathrm{Bu}$ & $n-\mathrm{BuLi}$ & $\mathrm{Et}_{2} \mathrm{O}$ & -78 & 165 \\
$\mathrm{OCONMe}_{2}$ & $\mathrm{LDA}$ & $\mathrm{THF}$ & -78 & 166,167 \\
$\mathrm{OCONEt}_{2}$ & $\mathrm{LDA}$ & $\mathrm{THF}$ & -78 & 166,167 \\
$\mathrm{CO}_{2} \mathrm{H}$ & $\mathrm{LTMP}$ & $\mathrm{THF}$ & -50 to -25 & 169 \\
$\mathrm{OMe}$ & $n-\mathrm{BuLi}$ & $\mathrm{Et}_{2} \mathrm{O}$ & 0 & 168 \\
$\mathrm{OMe}$ & $\mathrm{LTMP}$ & $\mathrm{THF}$ & -78 & 169 \\
$\mathrm{OEt}$ & $n-\mathrm{BuLi}$ & $\mathrm{Et}_{2} \mathrm{O}$ & 0 & 168 \\
$\mathrm{~F}$ & $\mathrm{LDA}$ & $\mathrm{THF}$ or THF/hexane & -78 & $135,170,171$ \\
$\mathrm{Cl}$ & $\mathrm{TDA}$ & $\mathrm{THF} /$ hexane & -75 & 172 \\
$\mathrm{CF}$ & $\mathrm{TDA}$ & $\mathrm{THF} /$ hexane & -75 & 173 \\
\hline
\end{tabular}

\subsection{Directed ortho-lithiation of diazines}

4.3.1 Directed ortho-lithiation of 1,2-diazines. Directed lithiation of pyridazines 20, containing a DMG at the C-3 position, has been achieved with LDA or LTMP to give the corresponding 4-lithio intermediates 21, which react with electrophiles to give 3,4-disubstituted pyridazines 22 (Scheme 8). ${ }^{150,174-180}$ Some examples of 3-substituted pyridazines 20 that have been subjected to directed lithiation, along with the appropriate reaction conditions, are shown in Table 6.

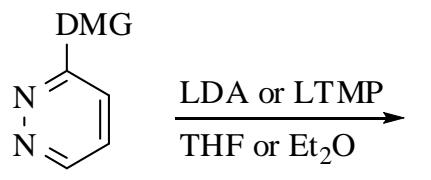

20

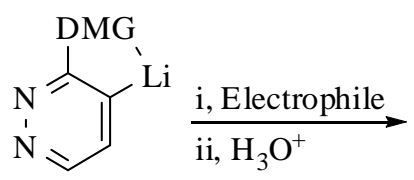

21<smiles>Cc1ccnnc1N(C)C</smiles>

22

$\mathrm{DMG}=\mathrm{SO}_{2} \mathrm{NH}^{t} \mathrm{Bu}, \mathrm{NHCO}^{t} \mathrm{Bu}, \mathrm{OMe}, \mathrm{OCH}_{2} \mathrm{CH}_{2} \mathrm{OMe}, \mathrm{Cl}$

Scheme 8. Directed lithiation of pyridazines 20 .

Table 6. Examples of 3-substituted pyridazines 20 lithiated according to Scheme 8

\begin{tabular}{ccccc}
\hline DMG & Lithium reagent & Solvent & T $\left({ }^{\circ} \mathrm{C}\right)$ & Reference \\
\hline $\mathrm{SO}_{2} \mathrm{NH}^{t} \mathrm{Bu}$ & LTMP & THF & -75 & 174 \\
$\mathrm{NHCO}^{t} \mathrm{Bu}$ & LDA or LTMP & THF & -78 & 175 \\
$\mathrm{OMe}$ & LTMP & THF & -78 & 176 \\
$\mathrm{OMe}$ & LDA or LTMP & THF & -75 & 150 \\
$\mathrm{OCH}_{2} \mathrm{CH}_{2} \mathrm{OMe}$ & LTMP & THF & -75 & 175 \\
$\mathrm{Cl}$ & LDA or LTMP & THF or Et ${ }_{2} \mathrm{O}$ & -100 to 0 & $177-180$ \\
\hline
\end{tabular}


4.3.2 Directed ortho-lithiation of 1,3-diazines. Directed lithiation of 4-substituted pyrimidines $\mathbf{2 3}$ takes place mainly at C-5 to give the corresponding 5-lithio intermediates $\mathbf{2 4}$, which on reactions with electrophiles give the corresponding 4,5-disubstituted pyrimidines 25 (Scheme 9; Table 7). ${ }^{136,176,177,181-188}$<smiles>Cc1ccncn1</smiles>

23<smiles>[R11][R]([H])=CC</smiles>

$$
\mathrm{DMG}=\mathrm{OMe}, \mathrm{F}, \mathrm{Cl}
$$

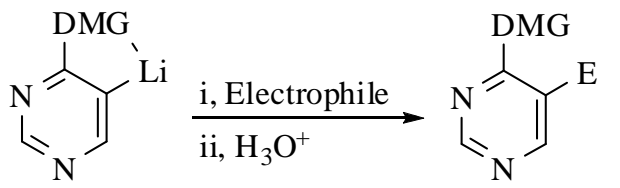

25

Scheme 9. Directed lithiation of 4-substituted pyrimidines 23.

Table 7. Examples of 4-substituted pyrimidines 23 lithiated according to Scheme 9

\begin{tabular}{ccccc}
\hline DMG & Lithium reagent & Solvent & $\mathrm{T}\left({ }^{\circ} \mathrm{C}\right)$ & Reference \\
\hline $\mathrm{OMe}$ & LDA & $\mathrm{Et}_{2} \mathrm{O}$ & 0 & 181 \\
$\mathrm{OMe}$ & LTMP & $\mathrm{THF}$ & -78 to -70 & $176,182-184$ \\
$\mathrm{~F}$ & $\mathrm{LDA}$ & $\mathrm{THF} \mathrm{or} \mathrm{Et}_{2} \mathrm{O}$ & -70 & 185 \\
$\mathrm{Cl}$ & $n-\mathrm{BuLi}$ & $\mathrm{THF}$ & -75 & 176 \\
$\mathrm{Cl}$ & $\mathrm{LDA}$ & $\mathrm{Et}_{2} \mathrm{O}$ & -80 & 186 \\
$\mathrm{Cl}$ & $\mathrm{LDA}$ & $\mathrm{THF}$ & -70 & 136,187 \\
$\mathrm{Cl}$ & LDA or LTMP & $\mathrm{THF}$ & -78 & 188 \\
\hline
\end{tabular}

4.3.3 Directed ortho-lithiation of 1,4-diazines. Directed lithiation of 2-substituted pyrazines 26 takes place at the 3-position (Scheme 10). ${ }^{174,184,189-196}$ Some examples of 2-substituted pyrazines 26 that have been subjected to such directed lithiation, along with the appropriate reaction conditions, are shown in Table 8. For example, directed lithiation of 2-(pivaloylamino)pyrazine (Scheme $10, \mathrm{DMG}=\mathrm{NHCO}^{t} \mathrm{Bu}$ ) was successful by the use of alkyllithiums in THF or $\mathrm{Et}_{2} \mathrm{O}$ as solvent to give the corresponding organolithium intermediate 27 $\left(\mathrm{DMG}=\mathrm{NHCO}^{t} \mathrm{Bu}\right)$, which on reactions with electrophiles produced the corresponding 2,3-disusbstituted pyrazines. ${ }^{189}$

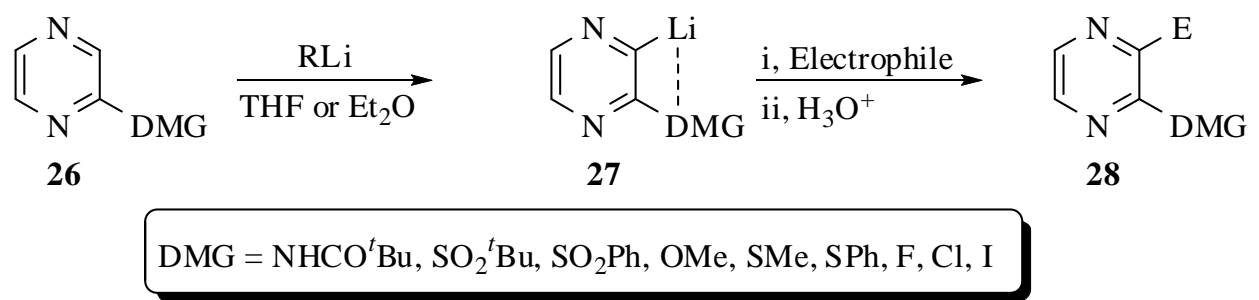

Scheme 10. Directed lithiation of 2-substituted pyrazines 26. 
Table 8. Examples of 2-substituted pyrazines $\mathbf{2 6}$ lithiated according to Scheme 10

\begin{tabular}{ccccc}
\hline $\mathrm{DMG}$ & $\mathrm{RLi}$ & Solvent & $\mathrm{T}\left({ }^{\circ} \mathrm{C}\right)$ & Reference \\
\hline $\mathrm{NHCO}^{t} \mathrm{Bu}$ & $\mathrm{R}=n$-Bu, $t$-Bu or LTMP & THF or Et ${ }_{2} \mathrm{O}$ & -70 to 20 & 189 \\
$\mathrm{SO}_{2}{ }^{\mathrm{Bu}}$ & LDA or LTMP & THF & -75 & 174 \\
$\mathrm{SO}_{2} \mathrm{Ph}$ & LDA & THF & -75 & 190 \\
$\mathrm{OMe}$ & LDA or LTMP & THF & -78 to 0 & $191-193$ \\
$\mathrm{SMe}$ & LTMP & THF & -75 & 190 \\
$\mathrm{SPh}$ & LTMP & THF & -78 & 191 \\
$\mathrm{~F}$ & LTMP & THF & -75 & 184,194 \\
$\mathrm{Cl}$ & LTMP & THF & -70 & 195 \\
$\mathrm{I}$ & LTMP & THF & -78 & 196 \\
\hline
\end{tabular}

\subsection{Directed ortho-lithiation of cinnolines}

3-Substituted cinnolines $(\mathrm{OMe}, \mathrm{Cl})$ have been lithiated with LTMP or LDA at $\mathrm{C}-4$, while the 4-substituted analogues have been lithiated at C-3. ${ }^{196}$ For example, 3-methoxycinnoline (29) has been lithiated at C-4 by use of LTMP or LDA in THF at $-75^{\circ} \mathrm{C}$ to give the lithium reagent 30 which reacted with various electrophiles to give the corresponding 4-substituted 3-methoxycinnolines 31 (Scheme 11) in high yields. ${ }^{196}$<smiles>COc1cc2ccccc2nn1</smiles>

29<smiles>COc1nnc2ccccc2c1[Al]</smiles>

30<smiles>COc1nnc2ccccc2c1F</smiles>

31

Scheme 11. Directed lithiation of 3-methoxycinnoline 29.

\subsection{Directed ortho-lithiation of $3 \mathrm{H}$-quinazolin-4-ones}

Directed lithiation of $3 \mathrm{H}$-quinazolin-4-ones has been investigated. ${ }^{197-200}$ For example, directed lithiation of 3-acylamino-3H-quinazolinones $\mathbf{3 2}$ was successful by the use of LDA in THF at $-78{ }^{\circ} \mathrm{C}$ to give the dilithium reagents $\mathbf{3 3}$ (Scheme 12). Reactions of $\mathbf{3 3}$ with electrophiles gave the corresponding 2-substituted 3-acylamino-3H-quinazolinones $\mathbf{3 4}$ in very good yields. ${ }^{197}$ By contrast, reactions of $\mathbf{3 2}$ with alkyllithiums led to the production of 1,2-addition products in excellent yields. ${ }^{197}$

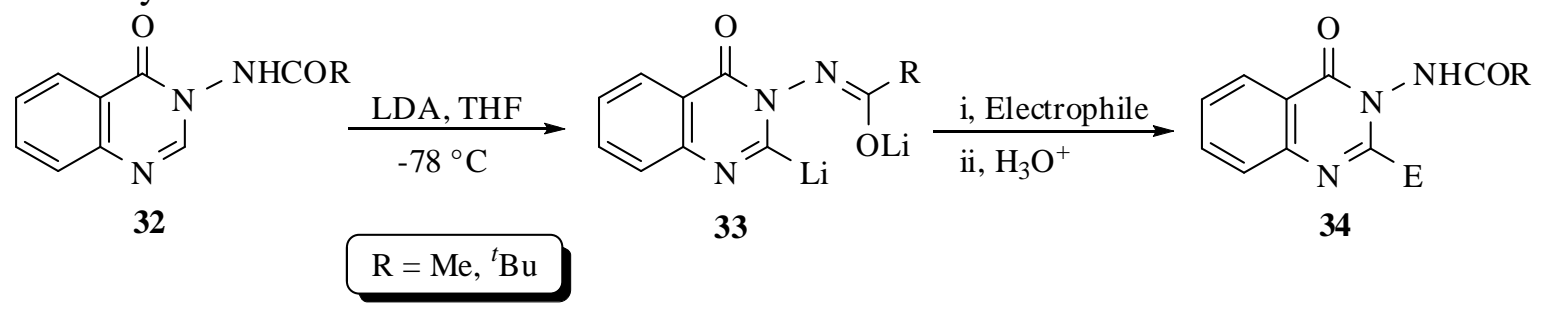

Scheme 12. Directed lithiation of 3-acylamino-3H-quinazolinones 32. 


\subsection{Directed ortho-lithiation of quinoxalines}

Directed lithiation of 2-(pivaloylamino)quinoxaline (35) with LTMP in THF at $-78{ }^{\circ} \mathrm{C}$ was regioselective at position 3 to give dilithium reagent 36 (Scheme 13). ${ }^{191,200,201}$ Reactions of 36 with electrophiles produced the corresponding ortho-substituted derivatives 37 in modest yields. $^{201}$

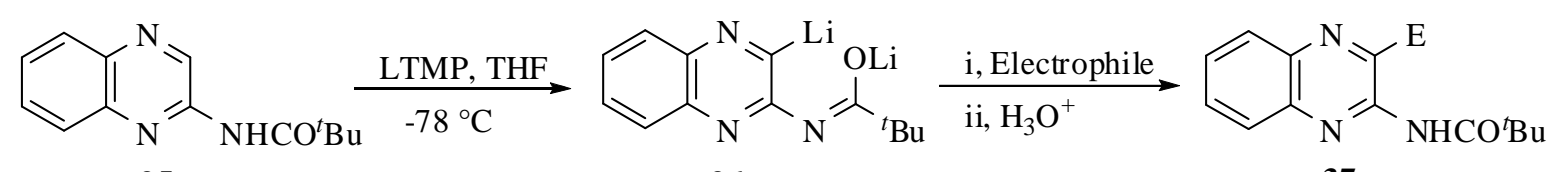
35

36

37

Scheme 13. Directed lithiation of 2-(pivaloylamino)quinoxaline (35).

\subsection{Directed ortho-lithiation of other heterocycles}

Directed lithiation of various other heterocycles has also been investigated. ${ }^{202-225}$ In some cases the ring heteroatom is sufficient to direct the lithiation to a site adjacent to the heteroatom, although the presence of a DMG may assist also. For example, directed lithiation of $N$-protected indoles 38 led to the production of 2-substituted $N$-protected indoles 40 (Scheme 14) ${ }^{203-207}$ Some examples of protected indoles $\mathbf{3 8}$ that have been subjected to directed lithiation, along with the appropriate reaction conditions, are recorded in Table 9.
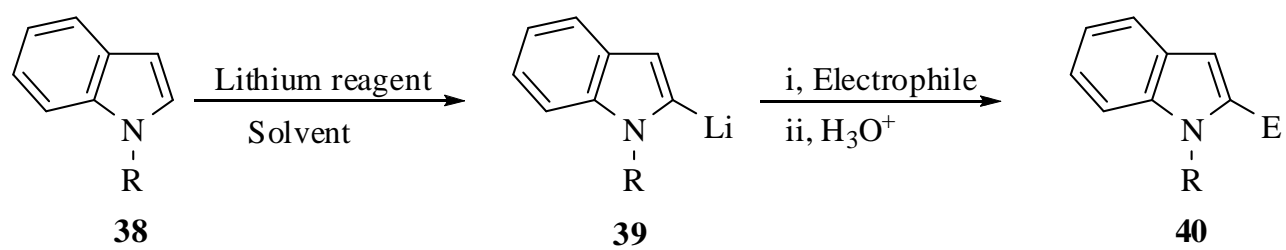

$\mathrm{DMG}=\mathrm{Me}, \mathrm{SO}_{2} \mathrm{Ph}, \mathrm{CO}_{2} \mathrm{H}, \mathrm{CO}_{2}{ }^{t} \mathrm{Bu}$

Scheme 14. Directed lithiation of $N$-protected indoles 38.

Table 9. Examples of $N$-substituted indoles $\mathbf{3 8}$ lithiated according to Scheme 14

\begin{tabular}{ccccc}
\hline $\mathrm{R}$ & Lithium reagent & Solvent & $\mathrm{T}\left({ }^{\circ} \mathrm{C}\right)$ & Reference \\
\hline $\mathrm{Me}$ & $n-\mathrm{BuLi}$ & $\mathrm{Et}_{2} \mathrm{O}$ & reflux & 204 \\
$\mathrm{Me}$ & $t-\mathrm{BuLi}$ & $\mathrm{THF}$ & -120 to -78 & 205 \\
$\mathrm{SO}_{2} \mathrm{Ph}$ & $\mathrm{MeLi}$ & $\mathrm{THF}$ & 0 & 203 \\
$\mathrm{SO}_{2} \mathrm{Ph}$ & $n-\mathrm{BuLi}$ & $\mathrm{Et}_{2} \mathrm{O}$ & reflux & 206 \\
$\mathrm{SO}_{2} \mathrm{Ph}$ & $t-\mathrm{BuLi}$ & $\mathrm{THF}$ & 0 & 206 \\
$\mathrm{SO}_{2} \mathrm{Ph}$ & $t-\mathrm{BuLi}$ & $\mathrm{THF}$ & -120 to -78 & 205 \\
$\mathrm{CO}_{2} \mathrm{H}$ & $t-\mathrm{BuLi}$ & $\mathrm{THF}$ & -70 & 207 \\
$\mathrm{CO}_{2} \mathrm{H}$ & $t-\mathrm{BuLi}$ & $\mathrm{THF}$ & -120 to -78 & 205 \\
$\mathrm{CO}_{2}{ }^{t} \mathrm{Bu}$ & $t-\mathrm{BuLi}$ & $\mathrm{THF}$ & -78 & 203 \\
$\mathrm{CO}_{2}{ }^{t} \mathrm{Bu}$ & $t-\mathrm{BuLi}$ & $\mathrm{THF}$ & -120 to -78 & 205 \\
\hline
\end{tabular}


Lithiation of $N, N$-diethyl-1-(methoxymethyl)-1H-indole-3-carboxamide (41) with LDA gave the corresponding 2-lithio reagent $\mathbf{4 2}$, which on reaction with iodomethane and benzaldehyde gave the corresponding 2-substituted derivatives 43 (Scheme 15) in 91 and $82 \%$ yields, respectively. ${ }^{214}$ Lithiation of $N$-protected indole-3-carboxylic acid behaved in similar manner. ${ }^{214}$

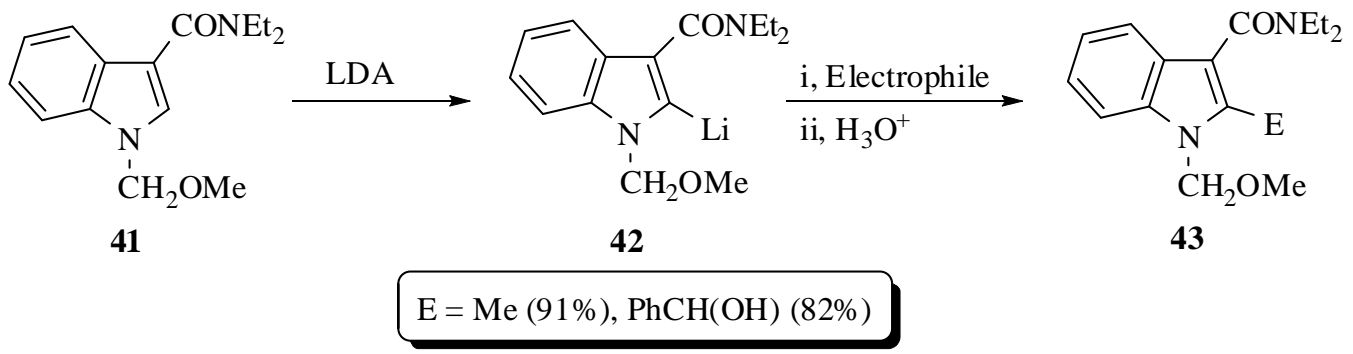

Scheme 15. Lithiation of $N, N$-diethyl-1-(methoxymethyl)-1H-indole-3-carboxamide (41).

Lithiation of benzofuran-3-carboxylic acid (44) with LDA in THF at $-78{ }^{\circ} \mathrm{C}$ gave the corresponding 2-lithio reagent $\mathbf{4 5}$, which on reaction with various electrophiles gave the corresponding 2-substituted derivatives 46 (Scheme 16) in $75-100 \%$ yields. ${ }^{215,216}$ Lithiation of benzofuran-2-carboxylic acid took place at the 3-position. ${ }^{216}$

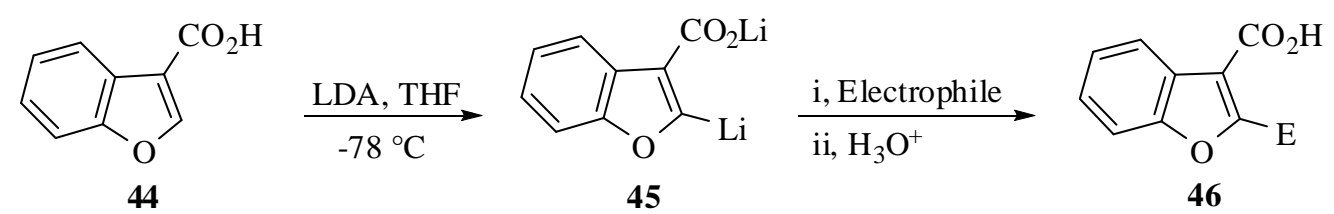

Scheme 16. Lithiation of benzofuran-3-carboxylic acid (44).

ortho-Lithiation of 3-(tert-butoxycarbonylamino)furan (47) with $t$-BuLi (2.5 equivalents) in the presence of TMEDA (2.5 equivalents) in THF at $-40{ }^{\circ} \mathrm{C}$ took place regioselectively at the C-2 position to provide the corresponding 2-lithio reagent 48 , which with trimethylsilyl chloride gave 3-(tert-butoxycarbonylamino)-2-(trimethylsilyl)furan (49) in 52\% yield (Scheme 17). ${ }^{218}$

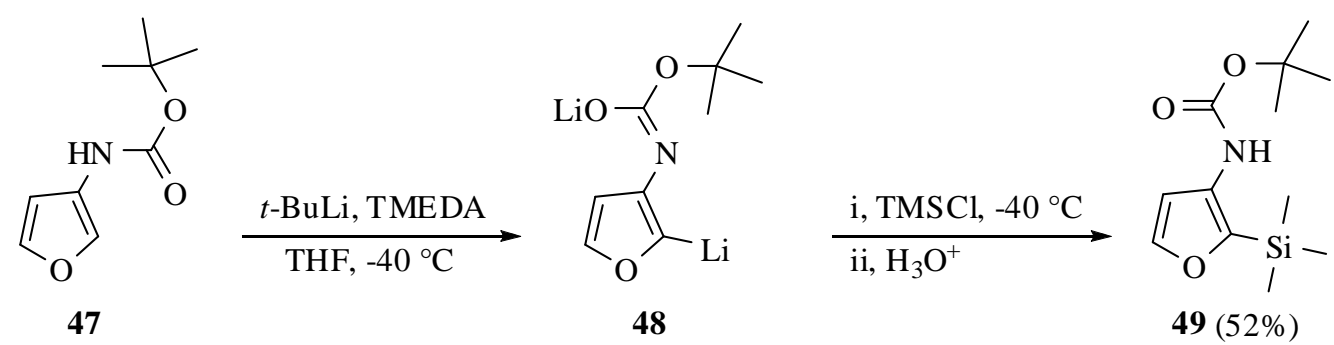

Scheme 17. Regioslective lithiation of 3-(N-tert-butoxycarbonyl)furan (47) at the C-2 position. 
In contrast, lithiation of $\mathbf{4 7}$ with $t$-BuLi (2.0 equivalents) in the absence of TMEDA in THF at $-20{ }^{\circ} \mathrm{C}$, followed by cyanation, took place at the C-5 position to give 5 -substituted derivative $\mathbf{5 1}$ in $71 \%$ yield via formation of lithium reagent $\mathbf{5 0}$ (Scheme 18). ${ }^{219,220}$

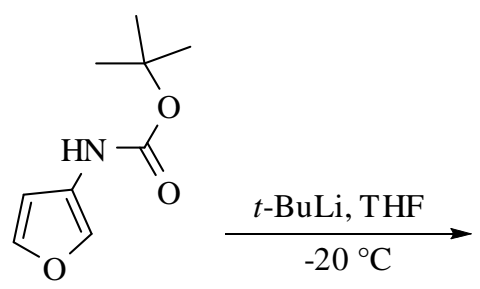

47

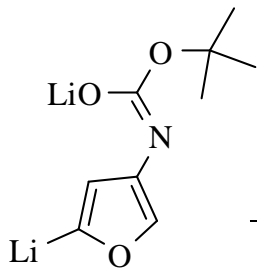

50

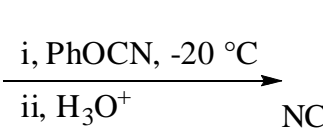

$\mathbf{5 1}(71 \%)$

Scheme 18. Regioslective lithiation of 3-(N-tert-butoxycarbonyl)furan (47) at the C-5 position.

\section{Conclusion}

Directed lithiation of various aromatics and heterocycles by lithium reagents at low temperatures and reactions of the lithium reagents thus obtained with electrophiles produces the corresponding ortho-substituted derivatives that might be difficult to prepare by other means.

\section{Acknowledgements}

The authors extend their appreciation to the Deanship of Scientific Research at King Saud University for its funding for this research through the research group project RGP-VPP-239.

\section{References}

1. Olah, G. A. Friedel-Crafts Chemistry; Wiley-Interscience: New York, 1973.

2. Roberts, R. M.; Khalaf, A. A. Friedel-Crafts Alkylation Chemistry; Marcel Dekker: New York, 1984.

3. Chemistry of Waste Minimisation; Clark, J. H., Ed.; Chapman and Hall: London, 1995.

4. Smith, K. In Catalysis of Organic Reactions; Scaros, M. G.; Prunier, M. L., Ed.; Marcel Dekker: New York, 1991, pp 91.

5. Smith, K. In New Aspects of Organic Synthesis II; Yoshida, Z.; Ohshiro, Y., Ed.; Kadonsha: Tokyo and VCH Weinheim, 1992, pp 43.

6. Butters, M. In Solid Supports and Catalysts in Organic Synthesis; Smith, K., Ed.; Ellis Horwood: Chichester, 1992, pp 130-170.

7. Delaude, L.; Laszlo, P.; Smith, K. Acc. Chem. Res. 1993, 26, 607-613. 
http://dx.doi.org/10.1021/ar00036a001

8. Catalysis of Organic Reactions using Supported Inorganic Reagents; Clark, J. H., Ed.; VCH: New York, 1994.

9. Clark, J. H. Acc. Chem. Res. 2002, 35, 791-797. http://dx.doi.org/10.1021/ar010072a

10. Smith, K.; El-Hiti, G. A. Curr. Org. Synth. 2004, 1, 253-274. http://dx.doi.org/10.2174/1570179043366747

11. Smith, K.; El-Hiti, G. A. Curr. Org. Chem. 2006, 10, 1603-1625. http://dx.doi.org/10.2174/138527206778249685

12. Smith, K.; El-Hiti, G. A. Green Chem. 2011, 13, 1579-1608. http://dx.doi.org/10.1039/c0gc00689k

13. Board, J.; Cosman, J. L.; Rantanen, T.; Singh, S. R.; Snieckus, V. Platinum Metals Rev. 2013, 57, 234-258. http://dx.doi.org/10.1595/147106713X672311

14. Beleńkii, L. I.; Evdokimenkova, Yu. B. Adv. Heterocycl. Chem. 2014, 111, 147-274.

15. Ogata, T.; Sugiyama, Y.; Ito, S.; Nakano, K.; Torii, E.; Nishiuchi, A.; Kimachi, T. Tetrahedron 2013, 69, 10470-10476. http://dx.doi.org/10.1016/j.tet.2013.09.081

16. Ramkumar, N.; Nagarajan, R. Tetrahedron Lett., 2014, 55, 1104-1106. http://dx.doi.org/10.1016/j.tetlet.2013.12.098

17. Porcs-Makkay, M.; Lukács, G.; Pandur, A.; Simig, G.; Volk, B. Tetrahedron 2014, 70, 286293. http://dx.doi.org/10.1016/j.tet.2013.11.058

18. Wakefield, B. J.; In Organolithium Methods; Katritzky, A. R.; Meth-Cohn, O.; Rees, C. W., Ed.; Academic Press: London, 1988.

19. Hartung, C. G.; Snieckus, V. The Directed ortho Metalation Reaction. A Point of Departure for New Synthetic Aromatic Chemistry, In Modern Arene Chemistry Astruc, D. Ed., WileyVCH, Weinheim, 2002, 330-367 and references cited therein.

20. Snieckus, V. Chem. Rev. 1990, 90, 879-933. http://dx.doi.org/10.1021/cr00104a001

21. El-Hiti, G. A. Heterocycles 2000, 53, 1839-1868. http://dx.doi.org/10.3987/REV-00-535

22. Schlosser, M. Eur. J. Org. Chem. 2001, 3975-3984. http://dx.doi.org/10.1002/1099-0690(200111)2001:21<3975::AID-EJOC3975>3.0.CO;2-\#

23. Clayden, J. Organolithiums: Selectivity for Synthesis, Pergamon: Oxford, 2002.

24. Schlosser, M. Organometallics in Synthesis, 2nd Ed.; Wiley: Chichester, 2002; pp 1-352.

25. Sugimoto, O.; Yamauchi, Y.; Tanji, K.-I. Heterocycles 2002, 57, 323-326. http://dx.doi.org/10.3987/COM-01-9386

26. Anctil, E. J.-G.; Snieckus, V. J. Organomet. Chem. 2002, 653, 150-160. http://dx.doi.org/10.1016/S0022-328X(02)01164-6 
27. Chinchilla, R.; Nájera, C.; Yus, M. Chem. Rev. 2004, 104, 2667-2722.

http://dx.doi.org/10.1021/cr020101a

28. Capriati, V.; Florio, S.; Luisi, R., Musio, B. Org. Lett. 2005, 7, 3749-3752.

http://dx.doi.org/10.1021/ol0514121

29. Smith, K., Barratt, M. L. J. Org. Chem. 2007, 72, 1031-1034. http://dx.doi.org/10.1021/jo062024f

30. Sánchez, J. D.; Cledera, P.; Perumal, S.; Avendaño, C.; Menéndez, J. C. Synlett 2007, 28052808.

31. Kliś, T.; Luliński, S.; Serwatowski, J.; Curr. Org. Chem. 2008, 12, 1479-1501. http://dx.doi.org/10.2174/138527208786241475

32. O'Neil, I. A.; Hitchin, J.; Bhamra, I.; Chorlton, A. P.; Tapolczay, D. J. Tetrahedron Lett. 2008, 49, 7416-7418.

http://dx.doi.org/10.1016/j.tetlet.2008.10.064

33. Stereochemical Aspects of Organolithium Compounds: Topics in Stereochemistry; Siegel, J. S., Ed.; 2010, Vol. 26.

34. Fukuda, T.; Ohta, T.; Sudo, E.-I., Iwao, M. Org. Lett. 2010, 12, 2734-2737.

http://dx.doi.org/10.1021/ol100810c

35. Tilly, D.; Fu, J.-M.; Zhao, B.-P.; Alessi, M.; Castanet, A.-S.; Snieckus, V.; Mortier, J. Org. Lett. 2010, 12, 68-71. http://dx.doi.org/10.1021/o1902268h

36. Volz, N.; Clayden, J. Angew. Chem. Int. Ed. 2011, 50, 12148-12155. http://dx.doi.org/10.1002/anie.201104037

37. Page, A.; Clayden, J. Beilstein J. Org. Chem. 2011, 7, 1327-1333. http://dx.doi.org/10.3762/bjoc.7.156

38. El-Hiti, G. A.; Hegazy, A. S.; Alotaibi, M. H.; Ajarim, M. D. Arkivoc 2012, (vii), 35-78. http://dx.doi.org/10.3998/ark.5550190.0013.704

39. Yañez Rodríguez, V.; Del Águila, M. Á.; Iglesias, M. J.; López Ortiz, F. Tetrahedron 2012, $68,7355-7362$.

40. El Hajjouji, H.; Belmonte, E.; García-López, J.; Fernández, I.; Iglesias, M. J.; Roces, L.; García-Granda, S.; El Laghdach, A.; López Ortiz, F. Org. Biomol. Chem. 2012, 10, 56475658.

http://dx.doi.org/10.1039/c2ob25395j

41. Tilly, D.; Magolan, J.; Mortier, J. Chem. Eur. J. 2012, 18, 3804-3820. http://dx.doi.org/10.1002/chem.201103920

42. Pearson, D. E.; Buehler, C. A. Synthesis, 1972, 533-542. http://dx.doi.org/10.1055/s-1972-21912

43. Wencel-Delord, J.; Glorius, F. Nature Chem. 2013, 5, 369-375. http://dx.doi.org/10.1038/nchem.1607

44. Colby, D. A.; Tsai, A. S.; Bergman, R. G.; Ellman, J. A. Acc. Chem. Res. 2012, 45, 814825 . 
http://dx.doi.org/10.1021/ar200190g

45. Vedernikov A. N. Acc. Chem. Res. 2012, 45, 803-813.

http://dx.doi.org/10.1021/ar200191k

46. Arockiam, P. B.; Bruneau, C.; Dixneuf, P. H. Chem. Rev. 2012, 112, 5879-5918. http://dx.doi.org/10.1021/cr300153j

47. Lewis, J. C.; Bergman, R. G.; Ellman, J. A. Acc. Chem. Res. 2008, 41, 1013-1025.

48. Roberts, J. D.; Curtin, D. Y. J. Am. Chem. Soc. 1946, 68, 1658-1660. http://dx.doi.org/10.1021/ja01212a090

49. Quéguiner, G.; Marsais, F.; Snieckus, V.; Epsztajn, J. Adv. Heterocycl. Chem. 1991, 52, 187-304. http://dx.doi.org/10.1016/S0065-2725(08)60965-4

50. Meyers, A. I.; Avila, W. B. Tetrahedron Lett. 1980, 21, 3335-3338. http://dx.doi.org/10.1016/S0040-4039(00)78682-5

51. Smith, K.; El-Hiti, G. A.; Abdo, M. A.; Abdel-Megeed, M. F. J. Chem. Soc., Perkin Trans. 1 1995, 1029-1033. http://dx.doi.org/10.1039/p19950001029

52. Smith, K.; El-Hiti, G. A.; Abdel-Megeed, M. F.; Abdo, M. A. J. Org. Chem. 1996, 61, 656661. http://dx.doi.org/10.1021/j09509891

53. Smith, K.; El-Hiti, G.A.; Hamilton, A. J. Chem. Soc., Perkin Trans. 1 1998, 4041-4042. http://dx.doi.org/10.1039/a808004f

54. Smith, K.; El-Hiti, G. A.; Pritchard, G. J.; Hamilton, A. J. Chem. Soc., Perkin Trans. 1 1999, 2299-2303.

http://dx.doi.org/10.1039/a903467f

55. Smith, K.; El-Hiti, G. A.; Hawes, A. C. Synlett 1999, 945-947.

56. Smith, K.; El-Hiti, G. A.; Abdel-Megeed, M. F.; Abdo, M. A. Collect. Czech. Chem. Commun. 1999, 64, 515-526.

http://dx.doi.org/10.1135/cccc19990515

57. Choppin, S.; Gros, P.; Fort, Y. Org. Lett. 2000, 2, 803-805. http://dx.doi.org/10.1021/ol0055380

58. Turck, A.; Plé, N.; Mongin, F.; Quéguiner, G. Tetrahedron 2001, 57, 4489-4505. http://dx.doi.org/10.1016/S0040-4020(01)00225-3

59. Gros, P.; Fort, Y. Eur. J. Org. Chem. 2002, 3375-3383. http://dx.doi.org/10.1002/1099-0690(200210)2002:20<3375::AID-EJOC3375>3.0.CO;2-X

60. Gros, P.; Louërat, F.; Fort, Y. Org. Lett. 2002, 4, 1759-1761. http://dx.doi.org/10.1021/o1025826f

61. Katritzky, A. R.; Manju, K.; Steel, P. J. J. Org. Chem. 2003, 68, 407-411. http://dx.doi.org/10.1021/jo026400h

62. Gros, P.; Choppin, S.; Fort, Y. J. Org. Chem. 2003, 68, 2243-2247. http://dx.doi.org/10.1021/jo026559u 
63. Smith, K.; El-Hiti, G. A.; Abdel-Megeed, M. F. Russ. J. Org. Chem. 2003, 39, 430-435. http://dx.doi.org/10.1021/jo026559u

64. Smith, K.; El-Hiti, G. A.; Hawes, A. C. Synthesis 2003, 2047-2052. http://dx.doi.org/10.1055/s-2003-41019

65. Smith, K.; El-Hiti, G. A.; Mahgoub, S. A. Synthesis 2003, 2345-2348. http://dx.doi.org/10.1055/s-2003-41064

66. El-Hiti, G. A. Synthesis 2003, 2799-2804. http://dx.doi.org/10.1055/s-2003-42486

67. El-Hiti, G. A. Synthesis 2004, 363-368. http://dx.doi.org/10.1055/s-2004-815923

68. Smith, K.; El-Hiti, G. A.; Abdel-Megeed, M. F. Synthesis 2004, 2121-2130. http://dx.doi.org/10.1055/s-2004-829169

69. El-Hiti, G. A. Monatsh. Chem. 2004, 135, 323-33. http://dx.doi.org/10.1007/s00706-003-0110-5

70. Smith, K.; El-Hiti, G. A.; Hegazy, A. S. Synthesis 2005, 2951-2961. http://dx.doi.org/10.1055/s-2005-916036

71. Smith, K.; El-Hiti, G. A.; Hegazy, A. S. J. Sulfur Chem. 2005, 26, 121-131. http://dx.doi.org/10.1080/17415990500151472

72. Smith, K.; El-Hiti, G. A.; Hegazy, A. S. Synlett 2009, 2242-2244. http://dx.doi.org/10.1055/s-0029-1217722

73. Smith, K.; El-Hiti, G. A.; Hegazy, A. S.; Fekri, A.; Kariuki, B. M. Arkivoc 2009, (xiv), 266300.

74. Smith, K.; El-Hiti, G. A.; Hegazy, A. S. Synthesis 2010, 1371-1380. http://dx.doi.org/10.1055/s-0029-1219277

75. Clayton, J.; Clayden, J. Tetrahedron Lett. 2011, 52, 2436-2439. http://dx.doi.org/10.1016/j.tetlet.2011.02.091

76. Smith, K.; El-Hiti, G. A.; Alshammari, M. B. Synthesis 2012, 44, 2013-2022. http://dx.doi.org/10.1055/s-0031-1291008

77. Smith, K.; El-Hiti, G. A.; Alshammari, M. B. J. Org. Chem. 2012, 77, 11210-11215. http://dx.doi.org/10.1021/jo3023445

78. Smith, K.; El-Hiti, G. A.; Fekri, A.; Alshammari, M. B. Heterocycles 2012, 86, 391-410. http://dx.doi.org/10.3987/COM-12-S(N)33

79. Chen, R.; Liu, H.; Liu, X.; Chen, X. Tetrahedron 2013, 69, 3565-3570. http://dx.doi.org/10.1016/j.tet.2013.02.079

80. Lenz, C.A.; Rychlik, M. Tetrahedron Lett. 2013, 54, 883-886. http://dx.doi.org/10.1016/j.tetlet.2012.11.123

81. Führer, W.; Gschwend, H. W. J. Org. Chem. 1979, 44, 1133-1136. http://dx.doi.org/10.1021/jo01321a023

82. Muchowski, J. M.; Venuti, M. C. J. Org. Chem. 1980, 45, 4798-4801. http://dx.doi.org/10.1021/jo01311a059 
83. Stanetty, P.; Koller, H.; Mihovilovic, M. J. Org. Chem. 1992, 57, 6833-6837. http://dx.doi.org/10.1021/jo00051a030

84. Smith, K.; El-Hiti, G. A.; Shukla, A. P. J. Chem. Soc., Perkin Trans. 1 1999, 2305-2313. http://dx.doi.org/10.1039/a903464a

85. Simig, G.; Schlosser, M. Tetrahedron Lett. 1988, 29, 4277-4280. http://dx.doi.org/10.1016/S0040-4039(00)80473-6

86. Katsoulos, K.; Schlosser, M. Tetrahedron Lett. 1993, 34, 6263-6264. http://dx.doi.org/10.1016/S0040-4039(00)73726-9

87. Smith, K.; El-Hiti, G. A.; Alshammari, M. B. Synlett 2013, 24, 117-119. http://dx.doi.org/10.1055/s-0032-1317859

88. Smith, K.; El-Hiti, G. A.; Alshammari, M. B. Synthesis 2014, 46, 394-402. http://dx.doi.org/10.1055/s-0033-1338570

89. Mao, C.-L.; Barnish, I. T.; Hauser, C. R. J. Heterocycl. Chem. 1969, 6, 475-482. http://dx.doi.org/10.1002/jhet.5570060405

90. Beak, P.; Brown, R. A. J. Org. Chem. 1982, 47, 34-46. http://dx.doi.org/10.1021/jo00340a008

91. Watanabe, M.; Sahara, M.; Kubo, M.; Furukawa, S.; Billedeau, R. J.; Snieckus, V. J. Org. Chem. 1984, 49, 742-747. http://dx.doi.org/10.1021/jo00179a002

92. Chen, C.-W.; Beak, P. J. Org. Chem. 1986, 51, 3325-3334. http://dx.doi.org/10.1021/jo00367a014

93. Sato, N. Tetrahedron Lett. 2002, 43, 6403-6404. http://dx.doi.org/10.1016/S0040-4039(02)01382-5

94. Reitz, D. B.; Massey, S. M. J. Org. Chem. 1990, 55, 1375-1379. http://dx.doi.org/10.1021/jo00291a058

95. Sibi, M. P.; Snieckus, V. J. Org. Chem. 1983, 48, 1935-1937. http://dx.doi.org/10.1021/jo00159a040

96. Evans, P. A.; Nelson, J. D.; Stanley, A. L. J. Org. Chem. 1995, 60, 2298-2301. http://dx.doi.org/10.1021/jo00112a067

97. Geneste, H.; Schäfer, B. Synthesis 2001, 2259-2262. http://dx.doi.org/10.1055/s-2001-18440

98. Rohonnstad, P.; Wensbo, D. Tetrahedron Lett. 2002, 43, 3137-3139. http://dx.doi.org/10.1016/S0040-4039(02)00490-2

99. Smith, K.; El-Hiti, G. A.; Hegazy, A. S. Synlett 2009, 2242-2244. http://dx.doi.org/10.1055/s-0029-1217722

100.Katsoulos, G.; Takagishi, S.; Schlosser, M. Synlett 1991, 731-732. http://dx.doi.org/10.1055/s-1991-34754

101.Tani, K.; Lukin, K.; Eaton, P. E. J. Am. Chem. Soc. 1997, 119, 1476-1477. http://dx.doi.org/10.1021/ja963658e

102.Schlosser, M.; Simig, G. Tetrahedron 1991, 32, 1965-1966. 
http://dx.doi.org/10.1016/0040-4039(91)85014-V

103.Figuly, G. D.; Loop, C. K.; Martin, J. C. J. Am. Chem. Soc. 1989, 111, 654-658. http://dx.doi.org/10.1021/ja00184a038

104.Block, E.; Eswarakrishnan, V.; Gernon, M.; Ofori-Okai, G.; Saha, C.; Tang, K.; Zubieta, J. J. Am. Chem. Soc. 1989, 111, 658-665. http://dx.doi.org/10.1021/ja00184a039

105.Smith, K.; Lindsay, C. M.; Pritchard, G. J. J. Am. Chem. Soc. 1989, 111, 665-669. http://dx.doi.org/10.1021/ja00184a040

106.Schlosser, M.; Mongin, F.; Porwisiak, J.; Damowski, W.; Büker, H. H.; Nibbering, N. M. M. Chem. Eur. J. 1998, 4, 1281-1286.

http://dx.doi.org/10.1002/(SICI)1521-3765(19980710)4:7<1281::AIDCHEM1281>3.0.CO;2-I

107.Gschwend, H. W.; Hamdan, H. J. Org. Chem. 1982, 47, 3652-3657. http://dx.doi.org/10.1021/jo00140a012

108.Parker, K. A.; Koziski, K. A. J. Org. Chem. 1987, 52, 674-676. http://dx.doi.org/10.1021/jo00380a034

109.Clayden, J.; Pink, J. H.; Yasin, S. A. Tetrahedron Lett. 1998, 39, 105-108. http://dx.doi.org/10.1016/S0040-4039(97)10443-9

110.Iwao, M.; Reed, J. N.; Snieckus, V. J. Am. Chem. Soc. 1982, 104, 5531-5533. http://dx.doi.org/10.1021/ja00384a064

111.Parker, K. A.; Koziski, K. A. J. Org. Chem. 1987, 52, 674-676. http://dx.doi.org/10.1021/jo00380a034

112.Bindal, R. D.; Katzenellenbogen, J. A. J. Org. Chem. 1987, 52, 3181-3185. http://dx.doi.org/10.1021/jo00391a001

113.Coll, G.; Morey, J.; Costa, A.; Saa, J. M. J. Org. Chem. 1988, 53, 5345-5348. http://dx.doi.org/10.1021/jo00257a027

114.Brown, J. M.; Woodward, S. J. Org. Chem. 1991, 56, 6803-6809. http://dx.doi.org/10.1021/jo00024a019

115.Bowles, P.; Clayden, J.; Helliwell, M.; McCarthy, C.; Tomkinson, M.; Westlund, N. J. Chem. Soc., Perkin Trans. 1 1997, 2607-2616. http://dx.doi.org/10.1039/a701671i

116. Turner, J. A. J. Org. Chem. 1983, 48, 3401-3408. http://dx.doi.org/10.1021/jo00168a007

117.Smith, K.; Anderson, D.; Matthews, I. Sulfur Lett. 1995, 18, 79-95.

118.Epsztajn, J.; Bieniek, A.; Kowalska, J. A. Tetrahedron 1991, 47, 1697-1706. http://dx.doi.org/10.1016/S0040-4020(01)96912-1

119.de Souza, M. V. N.; Dodd, R. H. Heterocycles 1998, 47, 811-827. http://dx.doi.org/10.3987/COM-97-S(N)84

120.Villacampa, M.; de la Cuesta, E.; Avendaño, C. Tetrahedron 1995, 51, 1259-1264. http://dx.doi.org/10.1016/0040-4020(94)01004-J 
121.Epsztajn, J.; Bieniek, A.; Brzeziński, J. Z.; Joźwiak, A. Tetrahedron Lett. 1983, 24, 47354738. http://dx.doi.org/10.1016/S0040-4039(00)86243-7

122.Sammakia, T.; Hurley, T. B. J. Org. Chem. 1999, 64, 4652-4664. http://dx.doi.org/10.1021/j0982281n

123.Epsztajn, J.; Berski, Z.; Brzeziński, J. Z.; Joźwiak, A. Tetrahedron Lett. 1980, 21, 47394742. http://dx.doi.org/10.1016/0040-4039(80)88108-1

124.Cochennec, C.; Rocca, P.; Marsais, F.; Godard, A.; Quéguiner, G. Synthesis 1995, 321-324. http://dx.doi.org/10.1055/s-1995-3896

125.Quesnelle, C.; Iihama, T.; Aubert, T.; Perrier, H.; Snieckus, V. Tetrahedron Lett. 1992, 33, $2625-2628$.

http://dx.doi.org/10.1016/S0040-4039(00)79042-3

126. Shibutani, T.: Fujihara, H.; Furukawa, N. Tetrahedron Lett. 1991, 32, 2943-2946. http://dx.doi.org/10.1016/0040-4039(91)80656-Q

127.Shibutani, T.: Fujihara, H.; Furukawa, N. Tetrahedron Lett. 1991, 32, 2947-2948. http://dx.doi.org/10.1016/0040-4039(91)80657-R

128.Mongin, F.; Trécourt, F.; Quéguiner, G. Tetrahedron Lett. 1999, 40, 5483-5486. http://dx.doi.org/10.1016/S0040-4039(99)01053-9

129.Lazaar, J.; Rebstock, A.-S.; Mongin, F.; Godard, A.; Trécourt, F.; Marsais, F. Quéguiner, G. Tetrahedron 2002, 58, 6723-6728. http://dx.doi.org/10.1016/S0040-4020(02)00673-7

130.Josien, H.; Ko, S.-B.; Bom, D.; Curran, D. P. Chem. Eur. J. 1998, 4, 67-83. http://dx.doi.org/10.1002/(SICI)1521-3765(199801)4:1<67::AID-CHEM67>3.0.CO;2-F

131.Comins, D. L.; Baevsky, M. F.; Hong, H. A J. Am. Chem. Soc. 1992, 114, 10971-10972. http://dx.doi.org/10.1021/ja00053a049

132.Gros, P.; Fort, Y.; Caubère, P. J. Chem. Soc., Perkin Trans. 1 1997, 3071-3080. http://dx.doi.org/10.1039/a701914i

133.Rocca, P.; Cochennec, C.; Marsais, F.; Thomas-dit-Dumont, L.; Mallet, M.; Godard, A.; Quéguiner, G. J. Org. Chem. 1993, 58, 7832-7838. http://dx.doi.org/10.1021/jo00079a031

134. Mallet, M. J. Organomet. Chem. 1991, 406, 49-56. http://dx.doi.org/10.1016/0022-328X(91)83170-9

135.Shi, G.-Q.; Takagishi, S.; Schlosser, M. Tetrahedron 1994, 50, 1129-1134. http://dx.doi.org/10.1016/S0040-4020(01)80824-3

136. Radinov, R.; Chanev, C.; Haimova, M. J. Org. Chem. 1991, 56, 4793-4796. http://dx.doi.org/10.1016/S0040-4020(01)80824-3

137. Mongin, F.; Tognini, A.; Cottet, F.; Schlosser, M. Tetrahedron Lett. 1998, 39, 1749-1752. http://dx.doi.org/10.1016/S0040-4039(98)00028-8

138. Gros, P.; Choppin, S.; Mathieu, J.; Fort, Y. J. Org. Chem. 2002, 67, $234-237$. 
http://dx.doi.org/10.1021/jo015855o

139.Alo, B. I.; Familoni, O. B.; Marsais, F.; Quéguiner, G. J. Heterocycl. Chem. 1992, 29, 6164.

http://dx.doi.org/10.1002/jhet.5570290109

140.Güngör, T.; Marsais, F.; Quéguiner, G. Synthesis 1982, 499-500. http://dx.doi.org/10.1055/s-1982-29855

141.Pomel, V.; Rovera, J.-C.; Godard, A.; Marsais, F.; Quéguiner, G. J. Heterocycl. Chem. 1996, 33, 1995-2005.

http://dx.doi.org/10.1002/jhet.5570330670

142.Godard, A.; Rocca, P.; Pomel, V.; Thomas-dit-Dumont, L.; Rovera, J.-C.; Thaburet, J.-F.; Marsais, F.; Quéguiner, G. J. Organomet. Chem. 1996, 517, 25-36. http://dx.doi.org/10.1016/0022-328X(95)05979-Y

143.Kelly, T. A.; Patel, U. R. J. Org. Chem. 1995, 60, 1875-1877. http://dx.doi.org/10.1021/jo00111a056

144.Smith, K.; El-Hiti, G. A.; Alshammari, M. B.; Fekri, A. Synthesis 2013, 45, 3426-3434. http://dx.doi.org/10.1055/s-0033-1338547

145.Wang, X.; Snieckus, V. Tetrahedron Lett. 1991, 32, 4883-4884. http://dx.doi.org/10.1016/S0040-4039(00)93486-5

146.Dormoy, J.-R.; Heymes, A. Tetrahedron 1993, 49, 2885-2914. http://dx.doi.org/10.1016/S0040-4020(01)80387-2

147.Guillier, F.; Nivoliers, F.; Bourguignon, J.; Dupas, G.; Marsais, F.; Godard, A.; Quéguiner, G. Tetrahedron Lett. 1992, 33, 7355-7356. http://dx.doi.org/10.1016/S0040-4039(00)60186-7

148.Guillier, F.; Nivoliers, F.; Godard, A.; Marsais, F.; Quéguiner, G.; Siddiqui, M. A.; Snieckus, V. J. Org. Chem. 1995, 60, 292-296. http://dx.doi.org/10.1021/jo00107a004

149.Beaulieu, F.; Snieckus, V. Synthesis 1992, 112-118. http://dx.doi.org/10.1055/s-1992-34150

150.Pollet, P.; Turck, A.; Plé, N.; Quéguiner, G. J. Org. Chem. 1999, 64, 4512-4515. http://dx.doi.org/10.1021/jo981125d

151.Trécourt, F.; Mallet, M.; Mongin, O.; Quéguiner, G. J. Org. Chem. 1994, 59, 6173-6178. http://dx.doi.org/10.1021/jo00100a017

152.Bertini, V.; Lucchesini, F.; Pocci, M.; De Munno, A. Heterocycles 1995, 41, 675-688. http://dx.doi.org/10.3987/COM-94-6945

153.Chambers, R. D.; Hall, C. W.; Hutchinson, J.; Millar, R. W. J. Chem. Soc., Perkin Trans. 1 1998, 1705-1714. http://dx.doi.org/10.1039/a709291a

154.Arzel, E.; Rocca, P.; Marsais, F.; Godard, A.; Quéguiner, G. J. Heterocycl. Chem. 1997, 34, $1205-1210$.

http://dx.doi.org/10.1002/jhet.5570340418 
155.Arzel, E.; Rocca, P.; Marsais, F.; Godard, A.; Quéguiner, G. Heterocycles 1999, 50, 215226. http://dx.doi.org/10.3987/COM-98-S(H)30

156.Gribble, G. W.; Saulnier, M. G. Heterocycles 1993, 35, 151-169. http://dx.doi.org/10.3987/COM-92-S1

157.Gu, Y. G.; Bayburt, E. K. Tetrahedron Lett. 1996, 37, 2565-2568. http://dx.doi.org/10.1016/0040-4039(96)00331-0

158.Ito, Y.; Kunimoto, K.; Miyachi, S.; Kako, T. Tetrahedron Lett. 1991, 32, 4007-4010. http://dx.doi.org/10.1016/0040-4039(91)80613-B

159.Choppin, S.; Gros, P.; Fort, Y. Eur. J. Org. Chem. 2001, 603-606. http://dx.doi.org/10.1002/1099-0690(200102)2001:3<603::AID-EJOC603>3.0.CO;2-2

160.Smith, K.; Lindsay, C. M.; Morris, I. K.; Matthews, I.; Pritchard, G. J. Sulfur Lett. 1994, 17 , 197-216.

161. Watson, S. E.; Markovich, A. Heterocycles 1998, 48, 2149-2155. http://dx.doi.org/10.3987/COM-98-8265

162.Trécourt, F.; Mallet, M.; Mongin, O.; Gervais, B.; Quéguiner, G. Tetrahedron 1993, 49, 8373-8380. http://dx.doi.org/10.3987/COM-98-8265

163.Numata, A.; Kondo, Y.; Sakamoto, T. Synthesis 1999, 306-311. http://dx.doi.org/10.1055/s-1999-3379

164.Robin, Y.; Godard, A.; Quéguiner, G. J. Heterocycl. Chem. 1987, 24, 1487-1488. http://dx.doi.org/10.1002/jhet.5570240553

165.Jacquelin, J. M.; Marsais, F.; Godard, A.; Quéguiner, G. Synthesis 1986, 670-672. http://dx.doi.org/10.1055/s-1986-31744

166.Godard, A.; Robin, Y.; Quéguiner, G. J. Organomet. Chem. 1987, 336, 1-12. http://dx.doi.org/10.1016/0022-328X(87)87152-8

167.Jacquelin, J. M.; Robin, Y.; Godard, A.; Quéguiner, G. Can. J. Chem. 1988, 66, 1135-1140. http://dx.doi.org/10.1139/v88-186

168. Narasimhan, N. S.; Paradkar, M. V.; Alurkar, R. H. Tetrahedron 1971, 27, 1351-1356. http://dx.doi.org/10.1016/S0040-4020(01)90886-5

169.Rebstock, A.-S.; Mongin, F.; Trécourt, F.; Quéguiner, G. Tetrahedron Lett. 2002, 43, 767769. http://dx.doi.org/10.1016/S0040-4039(01)02265-1

170.Arzel, E.; Rocca, P.; Marsais, F.; Godard, A.; Quéguiner, G. Tetrahedron Lett. 1998, 39, 6465-6466. http://dx.doi.org/10.1016/S0040-4039(98)01386-0

171.Arzel, E.; Rocca, P.; Marsais, F.; Godard, A.; Quéguiner, G. Tetrahedron 1999, 55, 12149 12156.

http://dx.doi.org/10.1016/S0040-4020(99)00715-2

172.Marsais, F.; Godard, A.; Quéguiner, G. J. Heterocycl. Chem. 1989, 26, 1589-1594. 
http://dx.doi.org/10.1002/jhet.5570260615

173.Marull, M.; Schlosser, M. Eur. J. Org. Chem. 2003, 1576-1588.

http://dx.doi.org/10.1002/ejoc.200390217

174.Turck, A.; Plé, N.; Pollet, P.; Quéguiner, G. J. Heterocycl. Chem. 1998, 35, 429-436. http://dx.doi.org/10.1002/jhet.5570350228

175.Turck, A.; Plé, N.; Ndzi, B.; Quéguiner, G.; Haider, N.; Schuller, H.; Heinisch, G. Tetrahedron 1993, 49, 599-606. http://dx.doi.org/10.1016/S0040-4020(01)86263-3

176.Lee, J. I.; Cho, S. H. Bull. Korean Chem. Soc. 1996, 17, 868-869.

177.Turck, A.; Plé, N.; Mojovic, L.; Quéguiner, G. J. Heterocycl. Chem. 1990, 27, 1377-1381. http://dx.doi.org/10.1002/jhet.5570270536

178. Mattson, R. J.; Sloan, C. P. J. Org. Chem. 1990, 55, 3410-3412. http://dx.doi.org/10.1021/jo00297a085

179.Plé, N.; Turck, A.; Couture, K.; Quéguiner, G. Synthesis 1996, 838-842. http://dx.doi.org/10.1055/s-1996-4303

180.Mojovic, L.; Turck, A.; Plé, N.; Dorsy, M.; Ndzi, B.; Quéguiner, G. Tetrahedron 1996, 52, 10417-10426. http://dx.doi.org/10.1016/0040-4020(96)00568-6

181.Wada, A.; Yamamoto, J.; Kanatoma, S. Heterocycles 1987, 26, 585-589. http://dx.doi.org/10.3987/R-1987-03-0585

182.Plé, N.; Turck, A.; Fiquet, E.; Quéguiner, G. J. Heterocycl. Chem. 1991, 28, 283-287. http://dx.doi.org/10.1002/jhet.5570280213

183.Plé, N.; Turck, A.; Bardin, F.; Quéguiner, G. J. Heterocycl. Chem. 1992, 29, 467-470. http://dx.doi.org/10.1002/jhet.5570290229

184.Plé, N.; Turck, A.; Heynderickx, A.; Quéguiner, G. Tetrahedron 1998, 54, 4899-4912. http://dx.doi.org/10.1016/S0040-4020(98)00173-2

185.Plé, N.; Turck, A.; Heynderickx, A.; Quéguiner, G. J. Heterocycl. Chem. 1994, 31, 13111315. http://dx.doi.org/10.1002/jhet.5570310602

186.Radinov, R.; Haimova, M.; Simova, E. Synthesis 1986, 886-891. http://dx.doi.org/10.1055/s-1986-31817

187.Plé, N.; Turck, A.; Martin, P.; Barbey, S.; Quéguiner, G. Tetrahedron Lett. 1993, 34, 16051608. http://dx.doi.org/10.1016/0040-4039(93)85019-S

188.Turck, A.; Plé, N.; Leprêtre-Gaquère, A.; Quéguiner, G. Heterocycles 1998, 49, 205-214. http://dx.doi.org/10.3987/COM-98-S17

189.Turck, A.; Plé, N.; Trohay, D.; Ndzi, B.; Quéguiner, G. J. Heterocycl. Chem. 1992, 29, 699702.

http://dx.doi.org/10.1002/jhet.5570290404 
190.Turck, A.; Plé, N.; Pollet, P.; Mojovic, L.; Duflos, J.; Quéguiner, G. J. Heterocycl. Chem. 1997, 34, 621-627. http://dx.doi.org/10.1002/jhet.5570340245

191.Ward, J. S.; Merritt, L. J. Heterocycl. Chem. 1991, 28, 765-768. http://dx.doi.org/10.1002/jhet.5570280336

192.Turck, A.; Trohay, D.; Mojovic, L.; Plé, N.; Quéguiner, G. J. Organomet. Chem. 1991, 412, 301-310.

193.Turck, A.; Plé, N.; Dognon, D.; Harmoy, C.; Quéguiner, G. J. Heterocycl. Chem. 1994, 31, 1449-1453.

http://dx.doi.org/10.1002/jhet.5570310627

194.Toudic, F.; Plé, N.; Turck, A.; Quéguiner, G. Tetrahedron 2002, 58, 283-293. http://dx.doi.org/10.1016/S0040-4020(01)01140-1

195.Plé, N.; Turck, A.; Heynderickx, A.; Quéguiner, G. Tetrahedron 1998, 54, 9701-9710. http://dx.doi.org/10.1016/S0040-4020(98)00526-2

196.Turck, A.; Plé, N.; Tallon, V.; Quéguiner, G. Tetrahedron 1995, 51, 13045-13060. http://dx.doi.org/10.1016/0040-4020(95)00835-V

197.Smith, K.; El-Hiti, G. A.; Abdel-Megeed, M. F.; Abdo, M. A. J. Org. Chem. 1996, 61, 647655.

http://dx.doi.org/10.1021/j0950988t

198.Plé, N.; Turck, A.; Chapoulaud, V.; Quéguiner, G. Tetrahedron 1997 53, 2871-2890. http://dx.doi.org/10.1016/S0040-4020(97)00046-X

199.Dai, X.; Virgil, S. Tetrahedron Asymmetry 1999, 10, 25-29. http://dx.doi.org/10.1016/S0957-4166(98)00496-0

200.Chapoulaud, V. G.; Salliot, I.; Plé, N.; Turck, A.; Quéguiner, G. Tetrahedron 1999, 55, 5389-5404.

http://dx.doi.org/10.1016/S0040-4020(99)00202-1

201.Turck, A.; Plé, N.; Tallon, V.; Quéguiner, G. J. Heterocycl. Chem. 1993, 30, 1491-1496. http://dx.doi.org/10.1002/jhet.5570300605

202.Chadwick, D. J.; Willbe, C. J. Chem. Soc., Perkin Trans. 1 1977, 887-893. http://dx.doi.org/10.1039/p19770000887

203.Hasan, I.; Marinelli, E. R.; Lin, L.-C. C.; Fowler, F. W.; Levy, A. B. J. Org. Chem. 1981, 46, 157-164.

http://dx.doi.org/10.1021/jo00314a034

204. Shirley, D. A.; Roussel, P. A. J. Am. Chem. Soc. 1953, 75, 375-378. http://dx.doi.org/10.1021/ja01098a035

205.Jiang, J.; Gribble, G. W. Tetrahedron Lett. 2002, 43, 4115-4117. http://dx.doi.org/10.1016/S0040-4039(02)00696-2

206.Sundberg, R. J.; Parton, R. L. J. Org. Chem. 1976, 41, 163-165. http://dx.doi.org/10.1021/jo00863a044

207.Katritzky, A. R.; Akutagawa, K. Tetrahedron Lett. 1985, 26, 5935-5938. 
http://dx.doi.org/10.1016/S0040-4039(00)98265-0

208.Doadt, E. G.; Sineckus, V. Tetrahedron Lett. 1985, 26, 1149-1152.

http://dx.doi.org/10.1016/S0040-4039(00)98419-3

209.Carpenter, A. J.; Chadwick, J. Org. Chem. 1985, 50, 4362-4368. http://dx.doi.org/10.1021/jo00222a032

210.Okada, E.; Masuda, R.; Hojo, M. Heterocycles 1992, 34, 791-798. http://dx.doi.org/10.3987/COM-91-5952

211.Hagen, T. J.; Rafferty, M. F.; Collins, J. T.; Garland, D. J.; Li, J. J.; Norton, M. B.; Reitz, D. B.; Tsymbalov, S.; Pitzele, B. S.; Hallinan, E. A. Heterocycles 1994, 38, 601-611. http://dx.doi.org/10.3987/COM-93-6598

212.Eriksen, B. L.; Vedsø, P.; Morel, S.; Begtrup, M. J. Org. Chem. 1998, 63, 12-16. http://dx.doi.org/10.1021/jo970355+

213.Eriksen, B. L.; Vedsø, P.; Begtrup, M. J. Org. Chem. 2001, 66, 8344-8348. http://dx.doi.org/10.1021/jo001554n

214.Buttery, D.; Jones, R.G.; Knight, D.W. Synlett, 1991, 315-316. http://dx.doi.org/10.1055/s-1991-20713

215.Buttery, C. D.; Knight, D. W.; Nott, A. P. Tetrahedron Lett. 1982, 23, 4127-4130. http://dx.doi.org/10.1016/S0040-4039(00)88366-5

216.Buttery, C. D.; Knight, D. W.; Nott, A. P. J. Chem. Soc., Perkin Trans. 1 1984, 2839-2843. http://dx.doi.org/10.1039/p19840002839

217.Knight, D. W.; Nott, A. P. J. Chem. Soc., Perkin Trans. 1 1983, 791-794. http://dx.doi.org/10.1039/p19830000791

218. Yeung, K.-S. Heterocycl. Chem. 2012, 29, 47-76.

219.Stanetty, P.; Kolodziejczyk, K.; Roiban, G.-D.; Mihovilovic, M. D. Synlett 2006, 789-791. http://dx.doi.org/10.1055/s-2006-933132

220.Sato, N.; Yue, Q. Tetrahedron 2003, 59, 5831-5836. http://dx.doi.org/10.1016/S0040-4020(03)00985-2

221.Grimaldi, T.; Romero, M.; Pujol, M. D. Synlett 2000, 1788-1792.

222.Mansueto, R.; Mallardo, V.; Perna, F. M.; Salomone, A.; Capriati, V. Chem. Commun. 2013, 49, 10160-10162. http://dx.doi.org/10.1039/c3cc45499a

223. Kacem, Y.; Hassine, B. B. Tetrahedron Lett. 2013, 54, 4023-4025. http://dx.doi.org/10.1016/j.tetlet.2013.05.082

224.Rewcastle, G. W.; Katritzky, A. R. Adv. Heterocycl. Chem. 1993, 56, 155-302. http://dx.doi.org/10.1016/S0065-2725(08)60195-6

225.Katritzky, A. R.; Lam, J. N.; Sengupta, S.; Rewcastle, G. W. Prog. Heterocycl. Chem. 1989, 1, 1-29. 


\section{Authors' Biographies}

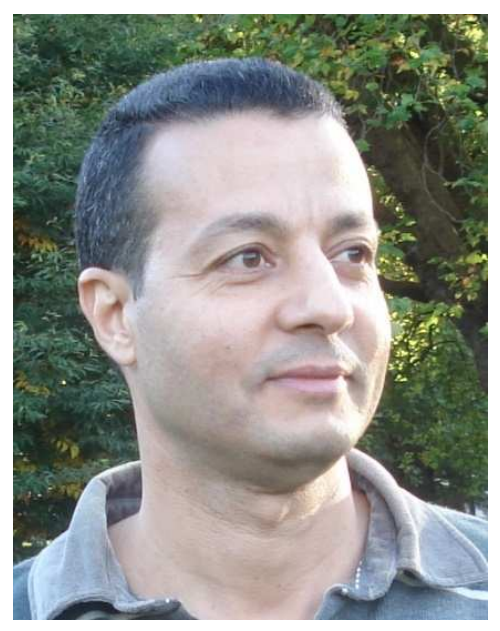

\section{Professor Gamal A. El-Hiti}

Gamal A. El-Hiti was born in Egypt. He received his BSc and MSc degrees from Tanta University, Egypt. He received his $\mathrm{PhD}$ degree from Tanta University in 1996 including two years at Swansea University, UK (Professor K. Smith). Lecturer (1996), Associate Professor (2001) and Professor (2006-2013), Tanta University (was on sabbatical leave to the UK; 19931995, 1998-1999 and 2002-2013). Academic Visitor, Swansea University (1998-1999). Lecturer and Research Officer, Swansea University (2002-2007). Research Fellow, Research Associate and Teacher in Organic Chemistry, Cardiff University (2007-2013). Technical Director of CatCelt Limited since 2006. His research interests are primarily in the development of novel organic synthetic methods, especially ones that are "greener" than traditionally, and synthesis of compounds with interesting properties. Particular current research projects involve use of zeolites and solid-supported reagents and catalysts to gain selectivity in organic reactions; lithiation reactions, which have been used to devise novel heterocyclic ring syntheses and to introduce selectivity into aromatic and heterocyclic substitution reactions; heterocyclic chemistry; design and synthesis of novel compounds with interesting chemiluminescent properties and chemistry of tears. He is currently a Professor of Organic Chemistry, since 2013, at King Saud University, College of Applied Medical Sciences, Department of Optometry, Saudi Arabia. 


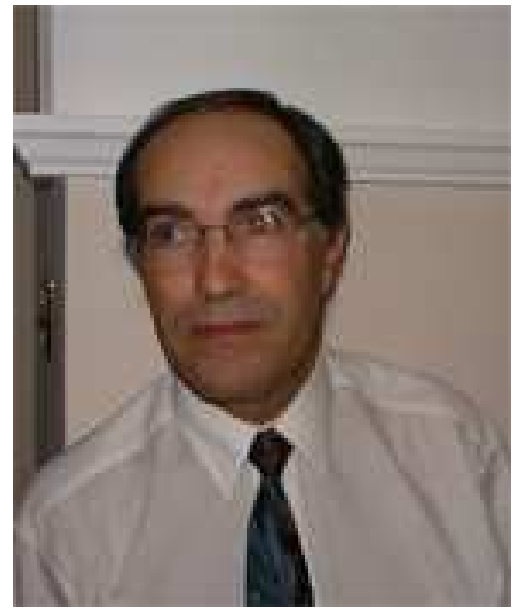

\section{Professor Keith Smith}

Keith Smith received his PhD degree from Manchester University in 1971 (Professor A. Pelter). Royal Society European Exchange Fellow, ETH Zürich (1971-1972; Professor A. Eschenmoser, chlorophyll derivatives). Lecturer, Swansea University (1972-1980). Visiting Research Associate, Purdue University West Lafayette IN USA (1978-1979; Professor H. C. Brown). Senior Lecturer and Reader Swansea University (1980-1988) and promoted to personal chair (1988). Head of Chemistry Department (1990-1993; 2001-2007). Professor of Organic Chemistry, Cardiff University (2007-2013). Managing Director of CatCelt Ltd since 2006. He is currently an Emeritus Professor, since 2013, at Cardiff University, UK.

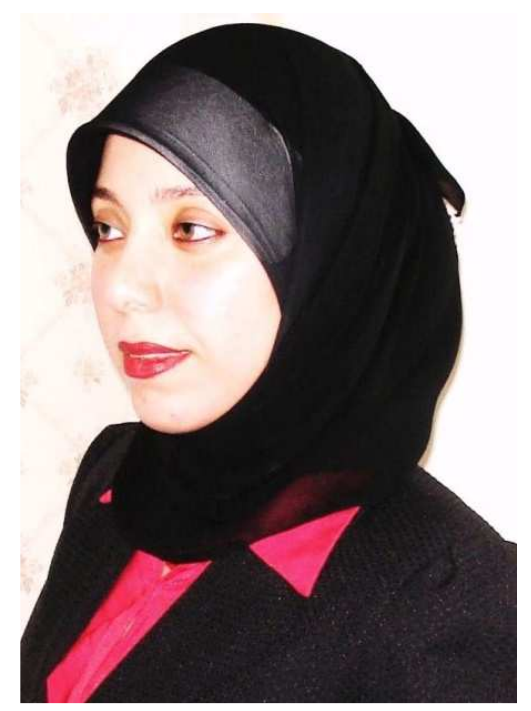

\section{Dr Amany S. Hegazy}

Amany S. Hegazy was born in Egypt. She received her B.Sc. degree in Chemistry from Tanta University, Egypt. She received her MPhil degree from Swansea University, UK, in 2006 and 
her Ph.D. degree from Cardiff University, UK, in 2009. She carried out her postgraduate studies under the supervision of Professor Keith Smith. Her research focused on the green synthetic methods of heterocycles and aromatics via use of organolithium reagents as intermediates in organic synthesis.

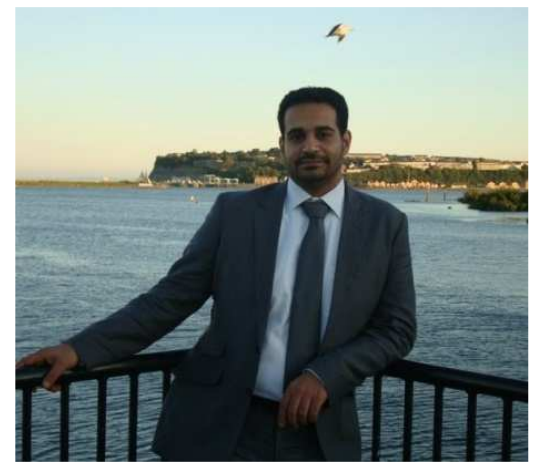

\section{Dr Mohammed B. Alshammari}

Mohammed B. Alshammari was born in Saudi Arabia. He received his B.Sc. and M.Sc. degrees in Chemistry from King Saud University, Saudi Arabia. He received his Ph.D. degree from Cardiff University, UK, in 2013 under the supervision of Professor Keith Smith. His research is focused on the use of organolithium reagents as intermediates in organic synthesis. Currently, he is working as Assistant Professor of Organic Chemistry at Salman bin Abdulaziz University, Saudi Arabia.

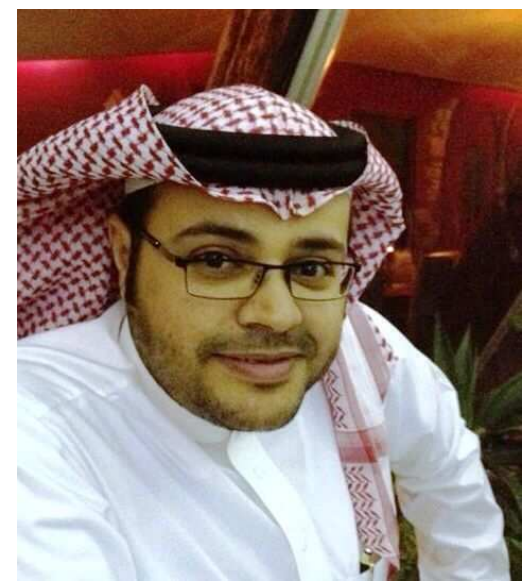

\section{Dr Ali M. Masmali}

Ali M. Masmali was born in Saudi Arabia. He received his B.Sc. degree in Optometry from King Saud University, Saudi Arabia, in 2002. He received his Ph.D. degree from Cardiff University, UK in 2010 under the supervision of Professor Paul Murphy and Professor Christine Purslow. His research is focused on the development of tear ferning test protocols and a new grading scale. Currently, he is working as Assistant Professor of Optometry at King Saud University, Saudi Arabia. 